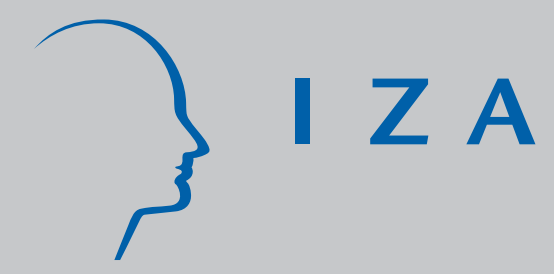

IZADP No. 2065

Capital Deepening and Wage Differentials: Germany vs. US

Winfried Koeniger

Marco Leonardi

April 2006 


\title{
Capital Deepening and Wage Differentials: Germany vs. US
}

\author{
Winfried Koeniger \\ IZA Bonn \\ and University of Bonn
}

\author{
Marco Leonardi \\ University of Milan \\ and IZA Bonn
}

\section{Discussion Paper No. 2065 \\ April 2006}

\author{
IZA \\ P.O. Box 7240 \\ 53072 Bonn \\ Germany \\ Phone: +49-228-3894-0 \\ Fax: +49-228-3894-180 \\ Email: iza@iza.org
}

\begin{abstract}
Any opinions expressed here are those of the author(s) and not those of the institute. Research disseminated by IZA may include views on policy, but the institute itself takes no institutional policy positions.

The Institute for the Study of Labor (IZA) in Bonn is a local and virtual international research center and a place of communication between science, politics and business. IZA is an independent nonprofit company supported by Deutsche Post World Net. The center is associated with the University of Bonn and offers a stimulating research environment through its research networks, research support, and visitors and doctoral programs. IZA engages in (i) original and internationally competitive research in all fields of labor economics, (ii) development of policy concepts, and (iii) dissemination of research results and concepts to the interested public.
\end{abstract}

IZA Discussion Papers often represent preliminary work and are circulated to encourage discussion. Citation of such a paper should account for its provisional character. A revised version may be available directly from the author. 


\section{ABSTRACT}

\section{Capital Deepening and Wage Differentials: Germany vs. US}

Capital deepening may affect the evolution of the wage differential between skilled and unskilled workers differently in countries with different labor market institutions. If labor market institutions raise the relative wage of unskilled workers in Germany, firms have incentives to invest relatively more into capital equipment complementary to unskilled workers. Instead in the US, where wage-compressing institutions are weaker, firms invest more in high-skilled workers. We provide evidence consistent with this view based on an industry panel for West Germany and the US between the 1970s and 1990s. We show that capital equipment per worker is less positively associated with the wage differential in West Germany than in the US. This descriptive evidence is robust to many alternative measures for capital and skills. Our estimates imply that capital deepening in Germany in the 1980s is associated with a reduction in the wage differential of about $10-20 \%$ in most industries. In the US instead, capital deepening is associated with an increase of the wage differential between 5 and $15 \%$ in most industries.

JEL Classification: E22, E24, J31, J64

Keywords: capital deepening, skill premium, wage floors, institutions

Corresponding author:

Winfried Koeniger

IZA

P.O. Box 7240

53072 Bonn

Germany

Email: koeniger@iza.org

\footnotetext{
* We thank our discussant Gianluca Violante and participants at the IZA workshop on "Structural Change and Labor Markets" for very helpful comments. Bertrand Koebel, Plutarchos Sakellaris and Focco Vijselaar, Gianluca Violante and Daniel Wilson kindly provided some of the data we use in our analysis. Financial support of DAAD-Vigoni is gratefully acknowledged.
} 


\section{INTRODUCTION}

Much of the recent policy discussion in developed countries revolves around labor markets (see Blanchard, 2006). The big differences in terms of unemployment and wage inequality between Anglo-Saxon and continental European countries have attracted particular interest. Governments in many continental European countries have recognized the unemployment problem for a long time but have mostly implemented only small reforms also because of distributional concerns. These concerns are paramount in many continental European countries like Germany. Slogans like 'Who does his job right, has to earn enough money to support his family' or 'It is shameful for a civilized society if human beings are put off with 3.50 euro per hour' make very clear that continental European societies have difficulties to accept the levels of inequality which prevail in Anglo-Saxon countries. ${ }^{2}$

Wages of workers in the US, for example, can be as low as $\$ 5.15$ per hour (4.32 euro at current exchange rates), which is the federal minimum wage. One important difference in Germany is that institutions like the generous welfare system and powerful unions induce wage floors which prevent wages of unskilled workers from falling to US levels. ${ }^{3}$ The common view is that institutional differences are related to the marked difference in the evolution of wage inequality in both countries. The wage differential between skilled and unskilled workers has remained remarkably stable in Germany whereas it has increased substantially in the US in the last decades (see Tables A.1. and A.2. which we will discuss further below). In this paper we link up these observations on institutions and wage differentials with another interesting difference between both countries which has received much less attention. The capital-labor ratio in Germany has increased more than in the US in the past 25 years.

The policy debate so far has mostly focused on the direct effect of institutions on wage inequality. Following Acemoglu and Pischke (1999) and Acemoglu (2003), we investigate how institutions affect wage differentials and also firm investment. We find evidence consistent with the view that German institutions distort investment towards unskilled workers and thus compress wage differentials relative to the US. We quantify this effect and argue that it is an important part of the overall effect of institutions on wage inequality. This finding has potentially important policy implications regarding the role of institutions for equality and efficiency. On the one hand institutions might have

\footnotetext{
${ }^{2}$ The citations are from the recent German debate on whether to introduce minimum wages, published in the weekly journal Stern. Müntefering (minister for labor and social affairs): "Wer seinen Job richtig macht, muss auch so viel Geld bekommen, dass er seine Famile davon ernähren kann.” Sommer (head of the German unions, DGB): "Dass Menschen für anständige Arbeit mit 3.50 Euro pro Stunde abgespeist werden, ist beschämend für eine zivilisierte Gesellschaft.” (Stern, 09.02.2006)

${ }^{3}$ The union membership rate was roughly twice as high in Germany compared with the US in the period 19701990, and has declined much less over time.
} 
stronger effects on wage inequality than commonly perceived (if both the standard direct effect and the indirect effect through investment matter). On the other hand institutions distort investment decisions in favor of unskilled workers. Since the productivity increases for unskilled workers are no 'free lunch', the investment distortions are costly for firms (as are the wage constraints per se) and employment falls.

The story we want to tell in this paper starts with the observation that the relative price of capital equipment has fallen at a higher rate since the mid 1970s. ${ }^{4}$ The fall in the relative price of capital equipment, increases the ratio of capital equipment per worker. This will increase the wage differential between skilled and unskilled workers if capital equipment is more complementary to skilled workers. This hypothesis has been put forward by Krusell et al. (2000) as possible explanation for the increase in the wage differential in the US.

We argue that the fall in the relative price of capital that induces more investment in capital equipment has a different effect on wage differentials in countries where institutions alter investment incentives for firms. These investment incentives depend on the skill of the worker whose labor is combined with capital equipment. If labor market institutions (such as the minimum wage or mandated benefits) increase the relative price of unskilled workers compared to the laissez-faire, firms might have an incentive to make these workers more productive in order to mitigate the institutional constraints. To make unskilled workers more productive, firms can either train the workers or invest in capital complementary to their low skills (Acemoglu and Pischke, 1999). That is firms might choose to invest in different types of capital goods in Germany compared with the US. For example, a conveyor belt seems particularly useful for unskilled workers whereas a high-tech machine for a chemical laboratory is more likely to be combined with skilled labor. These differences in capital investment might then help to explain the different association of capital equipment and wage differentials in the US and Germany in the last decades.

Our story does not necessarily imply simple capital-unskilled-labor substitution due to the higher cost of unskilled labor. Since labor markets are imperfect, firms and workers share rents. Then, firms may decide to invest into capital complementary to unskilled workers to increase their productivity and mitigate the institutional constraints.

We argue that this explanation is more attractive than the "Krugman hypothesis" or simple capital-unskilled-labor substitution. The "Krugman hypothesis" claims that the increase of the wage differential in the US and lower relative employment of unskilled workers in Germany are both due to a global adverse relative demand shift for unskilled workers. According to this hypothesis institutions prevented wages of the unskilled from falling in Germany and resulted in unemployment of the unskilled. Empirical evidence, however, has shown that the simple Krugman hypothesis is inconsistent with employment trends in Germany (see for example, Krueger and Pischke, 1998) since

\footnotetext{
${ }^{4}$ This phenomenon has been documented in detail by Krusell et al. (2000) and Cummins and Violante (2002) Since capital goods are traded in a global market this fall in the relative price is a common phenomenon for all developed countries.
} 
employment trends are similar across skill groups.

We provide descriptive evidence at the industry level on the association between capital-labor ratios and wage differentials in the US and Germany. This evidence is consistent with the theory that institutions have induced firms in Germany to invest more in unskilled-labor complementary capital. This evidence cannot be easily reconciled with the simple hypothesis of capital-unskilled-labor substitution since substitution would imply lower employment trends for unskilled workers relative to skilled workers which are not borne out in the data. Moreover, we show that the industries in Germany where the capital-labor ratio has increased the most are not the same as those industries where employment has risen the least; nor are these the industries where the skill intensity has increased the most. This suggests that simple substitution between capital and unskilled labor cannot explain our evidence.

\subsection{Related literature}

Many authors have emphasized the differences in the evolution of wage inequality across developed countries, and in particular between Germany and the US (see for example, Blau and Kahn, 1996; Beaudry and Green, 2003; and Abraham and Houseman, 1995). These differences have been partly attributed to skill-biased technical change but also to differences in labor market institutions (see for example Koeniger, Leonardi and Nunziata, 2004, and their references). Whereas the literature has been concerned mostly with the direct static effect of labor market institutions on wage inequality, in this paper we focus on their indirect effect resulting from distorted incentives to invest into capital equipment. Thus, we blend institutions and skill-biased investment as an explanation for the different evolution of wage differentials in the US and Germany.

Most closely related is the work of Beaudry and Green (2003) and Pischke (2005). Building on the same theory as in this paper, Pischke provides evidence that changes in investment between the 1990s and 1980s have been more pronounced in skill-intensive industries in OECD countries but less so in countries with smaller increases in wage inequality. Beaudry and Green (2003) draw a similar conclusion combining micro-data on wage-education profiles and aggregate data for capital in the US and Germany. They show that wage inequality between skilled and unskilled workers would have been smaller in the US if the capital accumulation in the US had matched the German pattern. Assuming that the newer technologies are both more skill complementary and more capital efficient, they show that the latter assumption implies that higher capital intensity induces a flatter wage-education profile. This paper instead builds on a theory which proposes institutions as one possible explanation for why countries use different capital intensities (similar to Pischke, 2005).

Importantly, we use data disaggregated by industry. Looking at industry variation within a country is a promising strategy because different industries demand different types of capital equipment so that the fall in the relative price for capital equipment affects industries differently. Moreover, labor market institutions have different effects 
on industries that use different technologies. Hence, industry and time variation can be helpful to identify the effects we are after. Another advantage is that we use data on capital equipment which is most relevant to study complementarities with different types of labor. Finally, the focus on two important countries allows us to use household data so that we can construct accurate measures of skilled and unskilled labor and wages by skill at the industry level.

The rest of the paper is structured as follows. In the next subsection we motivate our paper further with some descriptive evidence for the US and Germany. In Section 2 we present some theoretical background where a more formal derivation of the wage differential as a function of capital equipment is deferred to Appendix I. We then discuss the econometric specification. In Section 3 we present the data before we present the results and perform various robustness checks in Section 4. We discuss the results further in Section 5 before we conclude in Section 6 .

\subsection{Some descriptive evidence}

To motivate our analysis further, we illustrate the evolution of the main variables of interest in our sample period for two important industries. We choose two industries with medium skill intensity: the machinery industry as a representative industry for the manufacturing sector and the retail industry for the service sector. To make the figures comparable we normalize all variables to one in 1975.

Figure 1 displays the evolution of wage differentials by education and the capitalequipment per worker in the US and Germany. ${ }^{5}$ Wage differentials increased substantially in the US especially in the 1980s whereas they remained relatively stable in West Germany. On the contrary, the capital-labor ratio increased more in West Germany than in the US. The capital-labor ratio increased by $15 \%$ in the machinery sector and by $13 \%$ in the retail sector in Germany within the time period 1975 to 1990 . This is substantially higher than the $11 \%$ increase for both sectors in the US until 1990 (the vertical line in the right panels in Figure 1). Of course, the patterns observed in the figure are more or less pronounced depending on the respective industry. However, the descriptive graph sufficiently motivates a more detailed investigation in a regression framework after we have provided some theoretical background.

Since employment trends of skilled and unskilled workers in Germany have been similar in the sample period, the descriptive evidence cannot be explained by more substitution of unskilled labor in Germany. Differences in employment trends (for unskilled and

\footnotetext{
${ }^{5}$ We compare wages of workers with some college education with wages of workers with no college education. Below we describe more precisely how we construct the data series.
} 
skilled labor) in the US and Germany also cannot fully explain the different evolution of wage differentials and capital-labor ratios in Germany and the US (see section 5.1 below). Thus, it is worth investigating the alternative hypothesis that equipment has been more complementary to unskilled workers in Germany than in the US. 

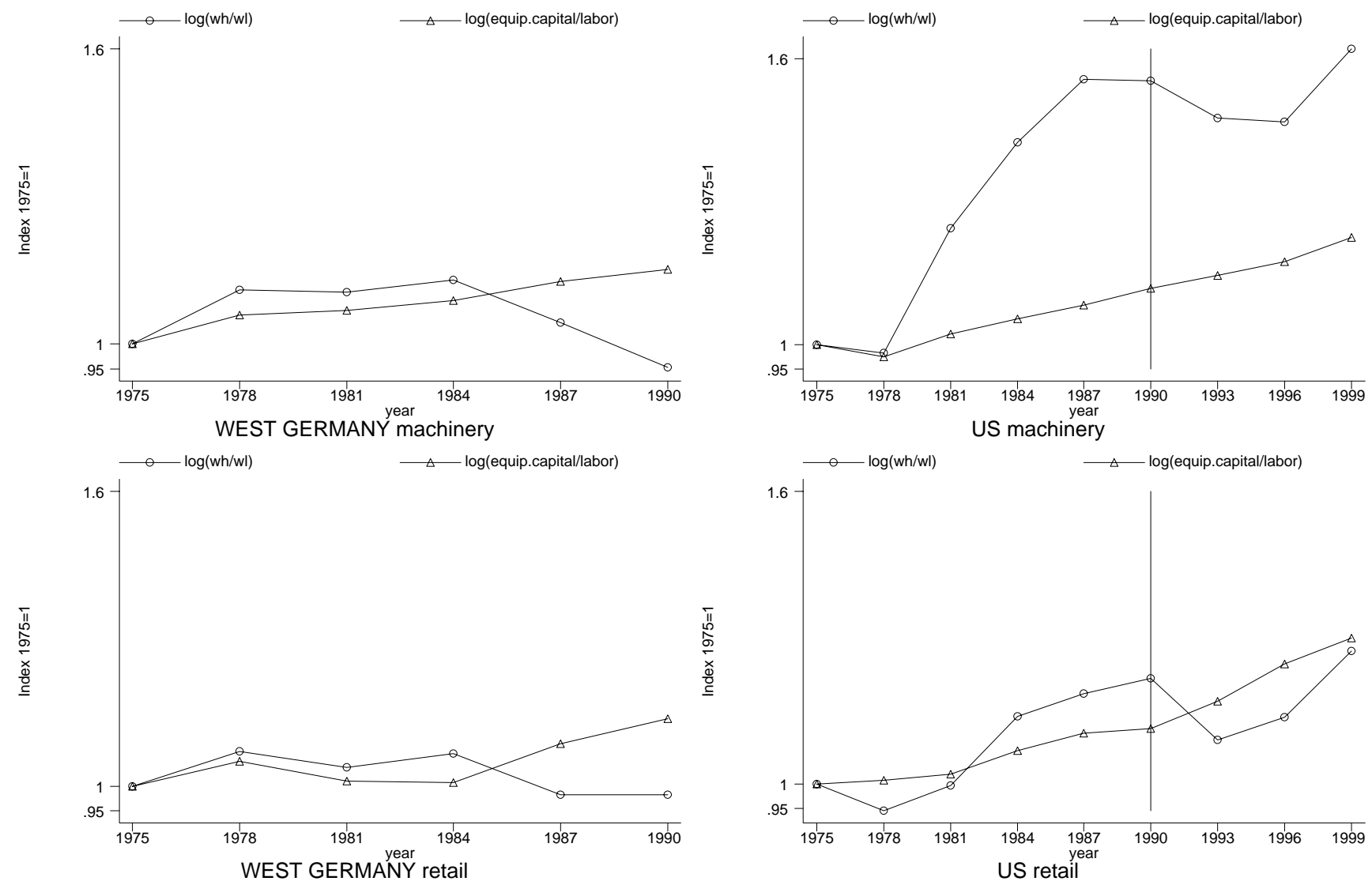

Figure 1. Wage differentials by skill and capital equipment per worker in the machinery and retail industry in the US and West Germany 1970s-1990s, three-year averages. Source: Authors' calculations based on CPS, IAB, and national accounts data. 


\section{THEORY AND EMPIRICAL PREDICTIONS}

In this section we derive empirical predictions using a simple model based on Acemoglu (2003). The main point, derived formally in Appendix I, is that firms have more incentives to enhance the productivity of unskilled workers if institutions like a minimum wage are binding. We argue that this scenario is plausible for Germany in which institutions like unions or implicit minimum wages induced by the social welfare system constrain the wage setting behavior of firms. Instead, in the US wage setting is not constrained by labor market institutions so that firms have less incentives to make unskilled workers more productive.

Important for our argument is that search frictions make labor markets imperfect, which is realistic. Firms post vacancies and workers search for jobs so that finding a match takes time for both parties. We assume that matches are found at random. Search frictions imply that a firm-worker match earns (quasi) rents (after the vacancy is matched) so that firms can afford to pay a minimum wage above the market wage. Moreover, the same worker can earn a different wage if he is matched to a different firm (in a different industry) since search frictions impede factor-price equalization across industries. Thus, the model implies inter-industry wage differentials and imperfect labor mobility.

The firm can choose whether to invest into a matched vacancy to improve the productivity of the worker. The investment costs the price $p_{k}$ and makes the worker $10 \%$ more productive for a given skill level. Note, that the absolute productivity increase is larger for skilled workers, however, so that productivity improvements are skillbiased. We assume that workers receive a fraction, say $1 / 2$, of their product which we assume to be four times higher for skilled workers. In this case the wage differential between skilled and unskilled workers is 4 in the flexible economy which we call "the US”. This is illustrated in Figure 2 which plots output and wages as a linear function of the skill level. Skilled workers with a skill level of 0.5 earn the wage 0.25 which is four times the wage 0.0625 of an unskilled worker with skill level 0.125.

Let us start from a situation where the price for capital is too high so that firms decide not to invest independent of whether they match their vacancy with a skilled or unskilled worker. Now assume that the price for capital equipment falls as is empirically realistic. For concreteness we assume that the new lower price is $p_{k}=0.01$. Then firms in the US find it optimal to invest if the vacancy is filled with a skilled worker. Figure 2 shows that the output increase of $10 \%$ amounts to 0.05 in this case (the difference between high and low-capital output at the skill level of 0.5 ). Half of this productivity increase needs to be shared with the skilled worker as wages increase so that the firm gains 0.025 . Since this gain is larger than the cost of 0.01 , the firm will invest into the vacancy if it is matched with a skilled worker. If the vacancy is matched with an unskilled worker instead, who has the skill level 0.125 , the gain of the firm is only $0.0125 / 2=0.00625$ which is smaller than the cost 0.01 . Hence, the firm will not invest into the vacancy if it is matched with 
an unskilled worker. As a result, the fall in the price $p_{k}$ implies an increase of the wage differential by $10 \%$.

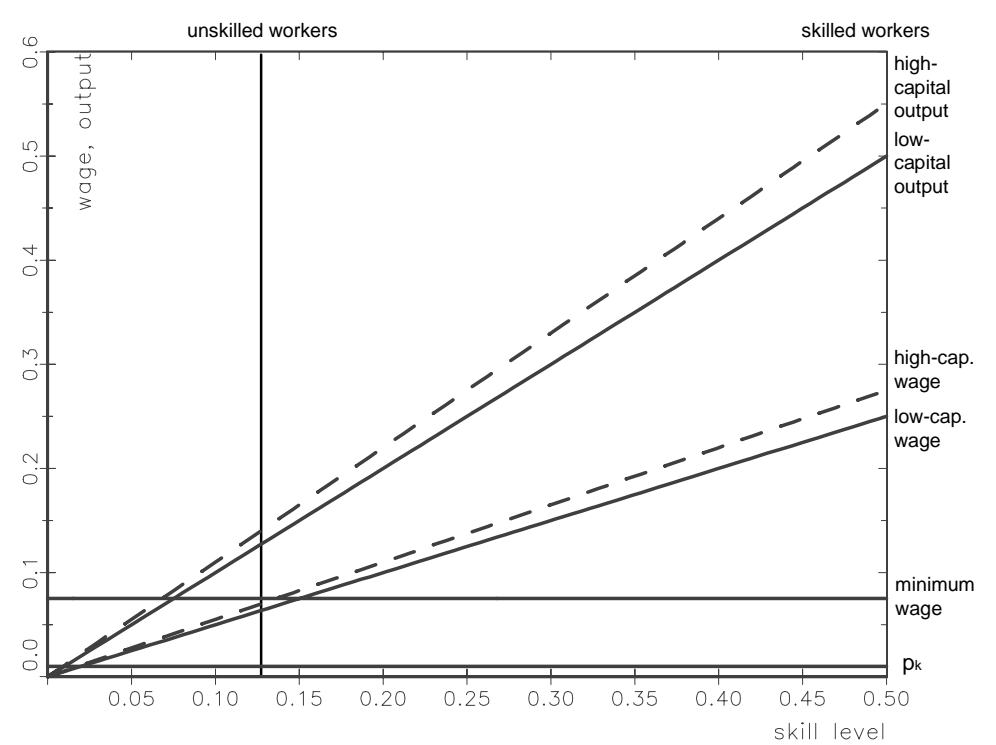

Figure 2. Wages and output by worker skill. Source: Authors' calculation based on the model in Appendix I.

This is the scenario which we believe is plausible for the US in the 1970s-1990s. Capital cheapening resulted in more investment complementary to skilled workers so that the wage differential increased. As shown in Appendix I, unemployment decreases as more vacancies are posted in equilibrium.

Now consider the economy with a binding minimum wage for unskilled workers which we call "Germany". As can be seen in Figure 2, the minimum wage of 0.075 is binding for skill levels below 0.15 if firms do not invest. Since the minimum wage is not binding for skilled workers (with a skill level 0.5) but for unskilled workers (with a skill level of 0.125), firms in Germany earn less than in the US if their vacancy is matched with unskilled workers. This is illustrated in Figure 3 by the parts of the vertical line that are called A and B. As in the US we assume that initially the price of capital is so high that vacancies are never invested in whether they are matched with skilled or unskilled workers. The minimum wage compresses the wage differential to $0.25 / 0.075=3.33$ in Germany compared with 4 in the US. The minimum wage also implies higher unemployment than in the US since less vacancies are posted by firms in equilibrium. 


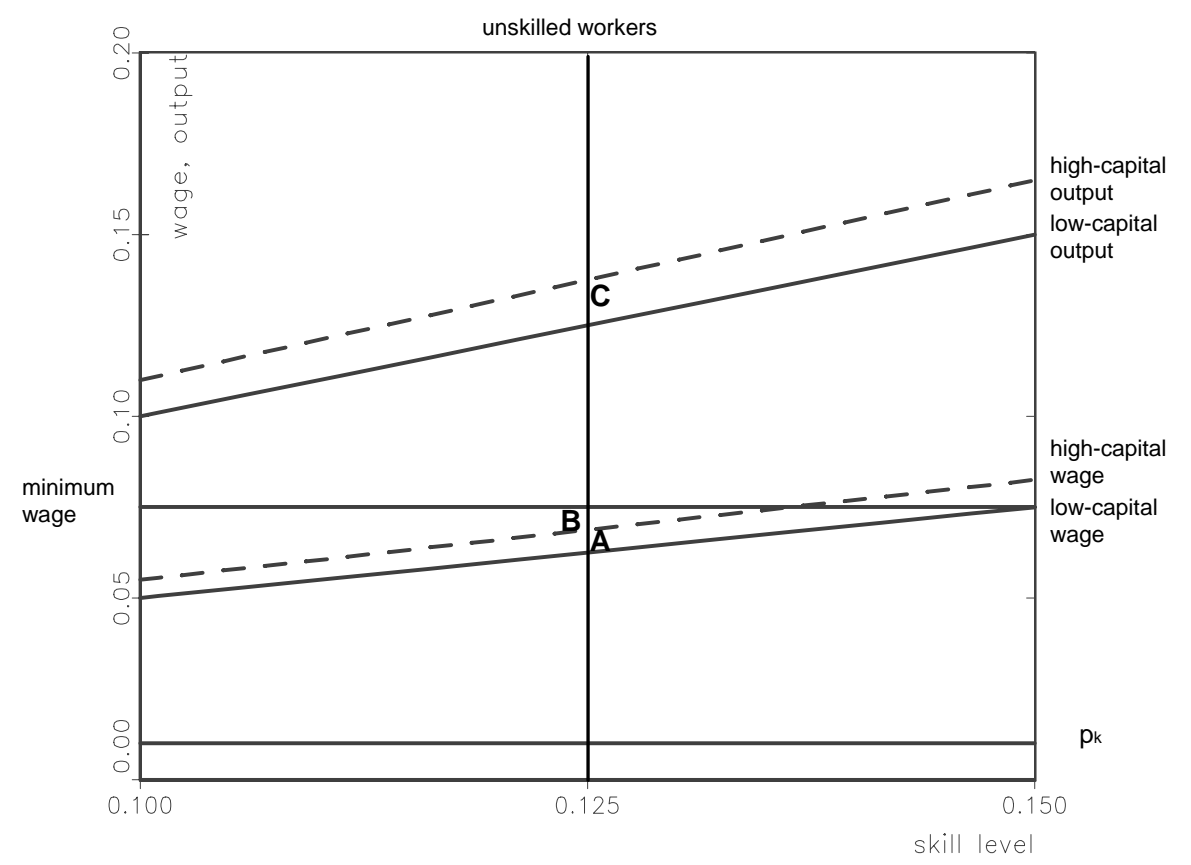

Figure 3. Wages and output of unskilled workers in detail. Source: Authors' calculation based on the model in Appendix I.

Again, consider a fall of the price for capital to 0.01 . This makes investment beneficial in Germany (as in the US) if vacancies are matched with skilled workers. The difference between both countries occurs for unskilled workers. The minimum wage makes investment beneficial in Germany where minimum wages are binding whereas this is not the case for the US. As can be seen in Figure 3, investment into a vacancy matched with an unskilled worker implies that the firm receives all the productivity gains (as illustrated by part $\mathrm{C}$ of the vertical line in Figure 3). Compared with the US, firms in Germany do not pass on part of the productivity gain to unskilled workers through wages (part A of the line in Figure 3). The wage of unskilled workers remains unchanged at the minimum wage. For our parameter values we find that the gain is 0.0125 (the $10 \%$ productivity improvement) minus the cost of 0.01 so that the net gain 0.0025 is positive. The productivity improvements make the minimum wage less binding (the difference between the minimum wage and the worker's market wage shrinks to part B of the line in Figure 3).

Thus, compared with the US, capital cheapening induces investment for vacancies matched with unskilled workers. The wage differential increases less in Germany than in the US to $0.275 / 0.075=3.66$. This relative wage compression would be even stronger if the productivity increase implied that wages for unskilled workers increased above the 
minimum wage. Of course, because of the minimum wage, capital cheapening reduces unemployment less in Germany than in the US. ${ }^{6}$

To summarize, capital cheapening induces a smaller increase of the wage differential in Germany than in the US for two reasons:

(i) first, the minimum wage always implies smaller wage differentials even if vacancies matched with unskilled workers are not invested in. This is the standard direct wage-compressing effect.

(ii) second, and more interestingly, the minimum wage might induce additional capital investment complementary to unskilled workers which reduces the wage differential, strengthening the direct effect.

Note that in a standard neoclassical framework one would expect that minimum wages, which make unskilled labor more expensive, induce substitution by other factors like capital or skilled labor. This then could also explain the contemporaneous rise of the capital-labor ratio and stable wage differentials. ${ }^{7}$ As mentioned above, this hypothesis is not consistent with the similar employment trends for skilled and the unskilled workers (Krueger and Pischke, 1998). Therefore, institutions in Germany which distort investment of firms towards capital complementary to unskilled workers, are an alternative hypothesis which is worth investigating.

\subsection{Empirical specification and identification}

To test the theory we use industry-level data on wage inequality and the capital-labor ratio for the US and Germany. There are two difficulties in the empirical specification which tests the theory. The first difficulty is to link capital equipment directly to the skill level of workers. Therefore our underlying assumption is that if firms in low-skill intensive sectors invest more, they invest more in unskilled-complementary capital. The second difficulty is about testing the role of institutions. Since institutions vary only over time and not across industry in each country, we assume that institutions like minimum wages have more bite in industries which have a lower skill intensity.

We use industry-level data on wage inequality and the capital-labor ratio for the US and Germany. Given the assumptions above, the theory has two testable predictions. First, the capital-labor ratio should be more strongly positively correlated with the initial

\footnotetext{
${ }^{6}$ Minimum wages can improve efficiency in search and matching models if the Hosios condition does not hold (i.e, if the elasticity of the matching function with respect to the unemployment rate is different from the bargaining power of workers in the Nash-bargaining problem). In our model minimum wages have an additional adverse effect since the firm can only post one type of vacancy so that minimum wages, which reduce the number of posted vacancies, also lower the probability of a match with more productive skilled workers.

${ }^{7}$ If the production function has decreasing returns in each single factor, this implies that the more intensive use of capital or skilled labor results in a fall of their marginal product and relative return. This is not quite consistent with the empirical observation that absolute wages of skilled workers have risen. Moreover, the returns of capital cannot fall unless frictions impede capital mobility across countries or industries.
} 
skill intensity of the industry in the US than in Germany. Second, the theory predicts that capital complementary to skilled workers should have grown at similar rates both in the US and Germany while capital complementary to unskilled labor should have grown more in Germany. Hence, a higher capital-labor ratio in Germany should imply a smaller increase of the wage differential. In the empirical section we focus on the second prediction. We now briefly comment on the first prediction.

Before moving to the empirical specification let us remind the reader that the first prediction of the model, that the capital-labor ratio should be more strongly positively correlated with the initial skill intensity in countries with weaker institutions, is the focus of Pischke's (2005) paper. Using a sample of OECD countries, Pischke (2005) first regresses investment growth by industry and country on the average skill level by industry in the US (assuming that the skill-intensities are similar across countries). He finds that the association of investment growth with the skill intensity is more positive in Anglo-Saxon than in continental European countries. These are also the countries in which aggregate wage inequality has increased more. If the different changes in aggregate wage inequality are attributed to differences in labor market institutions (that is, here it is assumed that changes in wage inequality approximate institutions), this is then consistent with more investment growth in unskilled-intensive industries in countries where wage compression alters investment incentives. ${ }^{8}$

Using our industry panel in the US and Germany we find that the correlation between changes in the capital-labor ratio and the initial skill intensity in 1975 is positive and significant in the US but insignificant in Germany. This is consistent with the results of Pischke (2005).

Let us now turn to the second prediction. Under the assumptions of our model, the second prediction can be tested with a simple bivariate regression for wage differentials and capital-labor ratios. ${ }^{9}$ The theory would predict a stronger positive coefficient of capital equipment in the US (where industries invest in skill-complementary capital) than in Germany (where investment is distorted towards unskilled workers). We now discuss the assumptions and identification for this specification in more detail.

\footnotetext{
${ }^{8}$ Note that our empirical specification (in the box) is different: In our specifications we treat the evolution of industry-specific wage inequality as an outcome which is differently associated with investment into capital equipment in countries with different labor market institutions.

${ }^{9}$ See also the discussion of the specification in the box 1.
} 


\section{Box 1. Econometric specification}

Starting from the formal derivations of the simple theoretical model in Appendix I, we assume that output $y$ is a continuous function of capital combined with each type of worker, called skilled $s$ or unskilled $u$. Recall that each worker is matched to a vacancy and then the firm decides how much capital to invest into that vacancy. We now assume that for each vacancy matched to a worker with skill level $h_{j}, j=s, u$, output is given by $y_{j}=A_{j} h_{j} K^{\sigma_{j}}$ where $K$ is the stock of capital equipment per worker and $A_{j}$ is the factor productivity. For $1>\sigma_{s}>\sigma_{u}$ capital is more complementary to skilled workers. We assume that workers of type $j$ appropriate the fraction $\beta_{j}$ of production, i.e. $w_{j}=\beta_{j} A_{j} h_{j} K^{\sigma_{j}}$. Then, search frictions in our model imply that wages $w_{j}$ of skilled and unskilled workers differ across industries with different technologies and thus also different capital intensities. Denoting with $i$ the industry, $c$ the country and $t$ the time period, we write the wage differential between skilled and unskilled workers in the simple log-linear form:

$\ln \left(\frac{w_{s}}{w_{u}}\right)_{i t}^{c}=\ln \left(\frac{\beta_{s}}{\beta_{u}}\right)_{i t}^{c}+\ln \left(\frac{A_{s}}{A_{u}}\right)_{i t}^{c}+\ln \left(\frac{h_{s}}{h_{u}}\right)_{i t}^{c}+\left(\sigma_{s}-\sigma_{u}\right)^{c} \ln \left(K_{i t}^{c}\right)$.

Note that we assume that $\sigma_{j}$ only depends on the worker type and does not change across time or industry. This allows us to (i) identify the coefficient of capital equipment using data with industry-time variation in the US and Germany; and (ii) possibly attribute the differences in the coefficients to different types of capital equipment $K_{i t}^{c}$ in the two countries.

Technology differences between skilled and unskilled workers across industries in each country are captured by $\ln \left(A_{s} / A_{u}\right)_{i t}^{c}$. The term $\ln \left(h_{s} / h_{u}\right)_{i t}^{c}$ captures the relative skill content of workers with and without college degree, which is our baseline distinction between skills. Finally, $\ln \left(\beta_{s} / \beta_{u}\right)_{i t}^{c}$ denotes the relative bargaining power, or simply the relative share of production appropriated by skilled and unskilled workers across industries. Importantly, all three terms are unobservable so that they are part of the error term $u_{i t}^{c}$ in our econometric specification. If the relative factor productivity, the skill content and bargaining power remain constant over time, they are captured by the industry-specific constant $a_{i}^{c}$. Denoting the remaining noise as $\varepsilon_{i t}^{c}$, we get the simple baseline specification

$\ln \left(\frac{w_{s}}{w_{u}}\right)_{i t}^{c}=a_{i}^{c}+b^{c} \ln \left(K_{i t}^{c}\right)+\varepsilon_{i t}^{c}$.

where $a_{i}^{c}$ are industry dummies for each country. We estimate this baseline specification for the US. The hypothesis is then that wage-compressing labor market institutions in Germany induce more investment in capital equipment complementary to unskilled labor than in the US. Estimating the same equation for Germany we test whether

$b^{U S}>b^{G E R}$.

In order to control for changes over time in economy-wide skill-biased technology change, we also estimate specifications with aggregate year dummies. 


\section{$\underline{\text { Identification }}$}

In our basic specification, the main identification assumption is that the relative bargaining power of skilled and unskilled workers, the relative skill content and the relative factor productivity can be captured by industry and time dummies. While this assumption does not seem to be too problematic for the relative bargaining power, the assumption deserves more discussion for the relative factor productivity and the relative skill content.

The assumption that the skill bias of technology is captured by industry and time dummies implies a constant difference in the skill bias across industries and that the changes over time are common across industries. If technology changes are pervasive in the economy and similar across countries, we can use time variation within industries and for the whole economy to explain the different evolution of wage differentials in both countries. Of course, the different evolution of the wage differential in Germany and the US could be due to different degrees of skill-biased technology change in both countries (see the estimated specifications with different time trends). Since this alternative explanation is about different trends in "unobservables", this "residual" explanation is, in our view, less satisfactory. Skill-biased technology change remains an important estimation issue, however, if time and industry effects are not sufficient to control for the evolution of technology. Then, the error term might be correlated with the wage differential (the dependent variable) and capital equipment (the regressor) which induces a positive correlation that is not necessarily related to capital equipment and capital-skill complementarity. If the resulting estimation bias is not the same in the US and Germany, we cannot disentangle whether the different estimates result from differences in capital-equipment investment or technology change without further assumptions. This relates to the well-known identification problems when estimating production functions (see Diamond et al., 1978).

Changes in the skill content mean that, for example, college education in the 1970s implied relatively more skills than in the 1990s. We assume that these changes in the measurement of relative skills are common across industries so that they are captured by industry and time dummies. It is important to emphasize and discuss in this context an important implication of the model: the skill-intensity of an industry should only matter for the extent of capital investment in the US compared with Germany. That is, the skill intensity in an industry is not important for the wage differential directly. As can be seen in the formal derivations in Appendix I, only the aggregate skill-intensity matters for the amount of vacancies posted and thus equilibrium employment. ${ }^{10}$ This strong implication of the model depends on the assumption of how production occurs. There are complementarities between labor and capital but it is not important whether skilled and unskilled workers are combined in the production process. Thus, the product of an unskilled worker is independent of the amount of skilled workers who are matched to vacancies in the same industry. Moreover, search frictions imply that unskilled workers

\footnotetext{
${ }^{10}$ Search is random so that more skilled workers increase the expected productivity of a match. Since there are no industry-specific labor markets in our model, which is a reasonable approximation, only the aggregate supply of skilled workers matters.
} 
cannot be substituted by skilled workers without cost. This is an important difference of this standard search-and-matching model compared with neoclassical models. Since substitution of more costly unskilled labor might be considered plausible within the two decades of our sample period, we try to address the concern that changes in the wage differential and capital equipment might be spurious due to the omission of changes in the industry-specific skill intensity as a regressor. We estimate a specification where we allow the wage differential to depend on the industry-specific skill intensity and hours worked as controls. Since both variables vary over time, they control for changes in the labor input. It should be noted that both variables are endogenous in that regression specification since we did not find convincing instruments to address the endogeneity issue. Hence, the results should be interpreted with care.

The final identification problem regards the endogeneity of the capital-labor ratio and the role of institutions. Endogeneity of capital equipment is obviously also a concern in our baseline specification. In our model, the causality chain runs from labor market institutions like minimum wages to capital investment which is then reflected in the wage differential. Estimating the steady-state relationship which we have derived in the model makes it difficult to disentangle these two parts of the causality chain. Of course, we cannot use labor market institutions as instruments for capital equipment since institutions directly affect wage differentials (the so called exclusion restriction is clearly violated). ${ }^{11}$

Since we are not aware of an appropriate source of exogenous variation in our application, we try a more indirect way to shed some light on the mechanism of interest. We control directly for a set of labor market institutions in our regressions to check whether the differences in the coefficients between Germany and the US remain. We use aggregate OECD measures with time variation on minimum wages and union density for the US and union density for Germany (Germany has no economy-wide minimum wage. Minimum wages have only been introduced in some industries in the 1990s). The underlying idea in these regressions is that although the institutional environment is largely determined at the aggregate level, these institutions affect industries differently. ${ }^{12}$ These regressions will give some first insight whether the different effect of capital equipment on wage differentials remains once we control for aggregate institutional changes.

\section{DATA}

In this section we mention how we construct the data used for the analysis and briefly describe some of the variables before we provide the results of the estimations in the

\footnotetext{
${ }^{11}$ Of course, an additional difficulty is that labor market institutions themselves might depend on wage differentials and capital investment.

${ }^{12}$ We also interacted union density (and minimum wages for the US) with capital equipment. This allowed us to check whether capital equipment compresses wages more if, say, union density has increased. The limited sample size, however, prevents us from estimating these interactions with enough precision.
} 
next section. We construct an industry panel for Germany and the US, combining industry-level data on capital equipment investment with micro data on wages and employment by education level. We describe the data only briefly and refer to the data appendix for further details on variable construction and industry classification in the various data sources (Tables A.3 and A.4).

\section{Equipment capital}

We use data on capital equipment from the national accounts (Bureau of Economic Analysis and Statistisches Bundesamt, respectively). We construct the stock of capital equipment for Germany using the series on gross capital equipment formation and applying the perpetual inventory method. Capital equipment in both countries is deflated with the chain-price indices provided by the respective statistical office. Since these price deflators have been criticized for their accuracy, we check the robustness of our results below using an alternative deflator provided by Cummins and Violante (2002).

\section{Wages and employment}

Wages and employment by skill and industry are constructed using CPS data (May surveys and Outgoing Rotation Group) for the US and the dataset on the social-security records from the Institut für Arbeits- und Berufsforschung (IAB) for Germany. For both countries our sample includes employees in full-time employment, age 20-60 with potential labor market experience up to 39 years. In the German IAB dataset we only use the information on West-Germany and drop all East-German observations after 1990. This leaves us with an industry panel in the time period 1973-2001 for the US and 19751991 for West Germany. ${ }^{13}$ Since the adjustment of capital equipment takes time and we are interested in the medium and low-frequency variation of the data, we use three-year averages and check robustness of the results for five-year averages. This also helps us to reduce problems of measurement error in the data for higher frequencies.

We define skilled workers as those with at least some college in the US and at least Abitur (high-school degree) in Germany. This educational skill measure achieves some comparability (if imperfect) across the two countries because 13 years of schooling imply a high-school degree in Germany and some college in the US. All those with less education in the respective country are classified as unskilled. ${ }^{14}$ This measure implies that the skill ratio $(H / L)$ is much smaller in Germany, with a sample average of 0.1 , than in the US, with a sample average of 0.8 (see also the industry averages in Tables A.1 and A.2). The reason is that the education system in the US and Germany is very different. The German education system is a two-tier system in which vocational training is

\footnotetext{
${ }^{13}$ Although we manage to extend our sample period for West Germany to 1995 since some series are available until then, we prefer to omit these years in our estimations since disentangling East and West German data is not straightforward for all variables. Thus, in the estimations the West-German sample period is 1975-1991. In the estimations for the US the sample period is 1980-2001 whenever we weigh industry-observations by real value added. Note further that the CPS is a representative sample of all employees whereas the IAB dataset is a $1 \%$ random sample of employees with a social-security record.

${ }^{14}$ Although Fitzenberger et al. (2005) find evidence of underreporting of higher education degrees in the IAB data, these measurement issues play little role in Mincer-type wage regressions. Thus, measurement problems are less relevant in the estimations in which we use the skill premium resulting from such wage regressions.
} 
important to enter many occupations. Only those who intend to go to college obtain a formal high school degree (Abitur). Thus, college education is not as prevalent in Germany as in the US and approximately $60 \%$ of the working population in Germany between 1975 and 1991 had only a vocational degree. Hence, we also construct two alternative skill measures for Germany. One can be considered an upper bound and includes all employees with a vocational degree in the skilled group. In this case the sample average of the skill ratio is 3 (see Table A.2, second to last column). Since this skill ratio is substantially higher than in the US, we also construct an alternative measure where we only include in the skilled group those workers with vocational degree who are in a white-collar position (Angestellter). These vocational degrees should be most comparable to college education in the US. With this skill measure the resulting skillratios for Germany and the US are similar between 0.4 and 0.5 (see Table A.2, last column). However, the skill ratio is still quite high in Germany in some industries. For example, the skill ratio is 4 in the banking and insurance sector which has a lot of whitecollar workers. Because of these measurement problems we will check the robustness of our results for all of the three measures. Our preferred skill-measure is the first one which is based on some college education since it measures general skills. The other measures contain more firm-specific skills acquired through vocational training. These measures are more likely to be endogenous in our application: a firm can make a worker more productive with equipment capital or firm-specific training. Of course, as Acemoglu and Pischke (1999) point out the same applies to general training if minimum wages are binding but we suspect the endogeneity problem to be less severe for a measure of general skills. We do not believe that many workers are classified as having a high-school degree or some college in Germany just because firms have subsidized their general education due to wage compression.

$\underline{R} \& D$ intensity

We also report results regarding the relationship between industry-level R\&D intensity and wage inequality. $R \& D$ intensity is the $R \& D$ expenditure divided by value added. Value added comes from the 60-Industry Database available online at the Groningen Growth and Development Centre. The data on R\&D expenditure are from the StanAnberd database provided by the OECD. An obvious criticism of the OECD measure is that it need not be related to technology improvements in the same industry and country. As an alternative, we construct a measure of technology change embodied in one important input, capital equipment. This variable is based on data by Wilson (2002) who combines data on $R \& D$ expenditure for capital equipment goods with data on capital equipment inputs by industry.

\section{Descriptive statistics}

Tables A.1 and A.2 display the averages of the main variables of interest: the wage differential, skill intensity, capital equipment per worker and R\&D intensity. Besides reporting the averages for each industry in the 1970s, we compute the percentage changes across decades. Note that the changes for Germany in the second decade are 
only computed until the end of the sample period 1991. Instead the changes for the US include the whole 1990s. We also report the changes in hours worked per industry as a measure of changes of the labor input at the intensive margin.

Tables A.1 and A.2 show that the US and Germany diverged in terms of equipment capital per worker in some industries: the level was already higher in the 1970s in most German industries than in the US and grew at a higher rate for some industries in the subsequent decades. ${ }^{15}$ Tables A.1 and A.2 further show that the skill intensity increased across decades in all industries and in both countries. Changes in the capital equipment per worker have different signs across industries and countries, although capital equipment has increased in most industries.

Finally, Tables A.1 and A.2 show the well-known differences in the evolution of wage differentials in Germany and the US. Whereas wage inequality has increased in nearly all industries in the US and up to $12.1 \%$ within a decade in some industries, wage differentials have increased little or have even fallen in West Germany.

The bottom-line of Tables A.1 and A.2 is that the skill intensity has increased in most industries in both countries, wage inequality has increased in the US but has remained stable in Germany, and equipment capital (and R\&D investment) have increased at different rates and with different timing within industries in the two countries. We now turn to the results of the estimation.

\section{RESULTS}

Table 1 presents the estimation results for the US and West Germany, respectively. In columns (1) and (2) we present results of the simplest specification which includes only equipment capital per worker and industry dummies. This specification is estimated for the full sample of 20 industries. In columns (3) and (4) we add aggregate time dummies to control for other unobserved changes over time. In columns (5) to (8) we replace the time dummies with time-varying observables like skill intensity and hours worked or measures for the union density and the minimum wage. In columns (9) and (10) we estimate the benchmark specification of columns (1) and (2) for the twelve manufacturing industries in our sample. Since we are after medium to low-frequency variation in the data, we also check the robustness of our findings for five-year averages in columns (11) and (12). All specifications include industry dummies.

\section{Benchmark results}

The results of our benchmark specification in column (2) show that a one-percent increase of capital equipment per worker in West Germany is significantly associated with a 9 basis point decrease of the wage differential. For the US (column (1)) we find a positive and significant correlation between equipment capital and the wage differential: a one-percent increase of capital equipment per worker is associated with a 7 basis point

\footnotetext{
${ }^{15}$ The comparison of variables in levels across countries is always difficult because of measurement issues. This is particularly problematic for capital measures which are constructed with the inventory method. In the estimation part the coefficients are identified by changes of variables over time.
} 
increase of the wage differential.

For both countries the coefficients between capital equipment and the wage differential do not depend on a specific industry. The result is robust if we drop one industry at a time. More generally, the results are robust to restricting the sample to the manufacturing sector (see columns 9 and 10) and to using five-year averages (columns 11 and 12). The positive correlation is particularly strong for manufacturing industries in the US (see column 9). For the subsample of manufacturing industries the coefficient in Germany is negative, no longer significantly different from zero but significantly smaller than the coefficient for the US. The coefficient is positive and significant for the benchmark specification estimated on five-year averages in the US and negative significant in Germany (see columns 11 and 12).

The robust finding in Table 1 is that capital equipment and the wage differential are less positively associated in West Germany than in the US. This result is also robust if we use capital equipment per worker hour to control for differences in hours worked across countries, time and industries. The coefficients in such regressions are $0.065(0.026)$ for the US and -0.079 (0.027) for Germany where robust standard errors are in parentheses. Both coefficients are highly significant. Although the coefficients are not estimated precisely enough in some specifications of Table 1 to allow us to formally reject the hypothesis that the coefficients are the same in the US and Germany at standard significance levels, our evidence suggests that capital equipment is more complementary to unskilled workers in Germany than in the US. Consistently with our hypothesis we find that the point estimates $b^{G E R}<b^{U S} \cdot \cdot^{16}$

\section{Quantitative implications}

To gauge the quantitative size of the association between capital equipment and wage differentials in West Germany, we use the fitted values for the wage differential obtained from the benchmark regression specification in Table 1, column (2). We compare these predictions for the wage differential with the fitted values obtained holding capital equipment per worker constant at the initial level in 1975. Comparing the differences of these two measures of fitted wage differential at the end of the sample (1991), we find that the wage differential would have been about $10-20 \%$ higher in most industries had capital per worker remained unchanged. The industries where the accumulation of capital equipment per worker had the smallest effect on the wage differential are utilities, business and personal services and health services. The biggest effect of capital equipment per worker is in the banking sector where the wage differential would have been 49\% higher had the capital-labor ratio stayed at the same level as of 1975.

Doing the same exercise for the US (for the same time period until 1991), we find that if the capital-labor ratio had not grown beyond its 1975 level, the wage differential would have been between 5 to $15 \%$ lower than what was observed in 1991. Weighing these results by valued added in each industry we find an aggregate average change of $10 \%$. This number is smaller than the $18 \%$ estimated by Krusell et al. (2000) who use

${ }^{16}$ The different results for the US and Germany are not due to the different sample period in the 1990s. The coefficient of capital equipment for the US until 1991 is even more positive, 0.096, and highly significant. 
aggregate data and a different estimation method. ${ }^{17}$

\section{Time dummies}

In columns (3) and (4) in Table 1 we control for aggregate changes over time (for example, caused by economy-wide skill-biased technology change) which possibly can account for the different association between capital equipment and the wage differential in the two countries. The results show that the negative coefficient for capital equipment in Germany is robust when we control for time dummies (see column 4). This is not the case for the positive coefficient in the US (see column 3). Capital-skill complementarity and an increase of capital equipment after the fall of the price of equipment capital in the early 1970s are a possible explanation for the increase in the wage differential in the US but cannot be distinguished from any other explanation which implies a aggregate time trend like skill-biased technology change, changes in aggregate labor market conditions or employment patterns. Interestingly, however, the coefficient for Germany remains negative and significant (see column 4) so that the different effect of capital equipment on the wage differential cannot be explained fully by aggregate country-specific technology changes. If we allow for industry-specific time trends, the coefficients of equipment capital are no longer significant. The identifying variation is then the deviation from this trend, however, which is driven by industry-specific cyclical variation which is not what we are after. Thus the data do not allow us to reject country and industry-specific technology change, for example, as an alternative explanation for the different association between wage differentials and capital equipment in the US and West Germany.

\footnotetext{
${ }^{17}$ Krusell et al. (2000) use aggregate time-series variation and impose a constant-elasticity-of-substitution production function with four factors: capital equipment, capital structures, skilled and unskilled labor.

${ }^{18}$ Of course, besides union density the effect of unions is determined by union coverage, i.e. the proportion of contracts covered by collective agreements. Data on union coverage has the advantage of giving more weight to unions in countries where the density is quite low but the bargaining power is high. However, consistent series on union coverage are not available, apart for a few observations every 10 years (see Nickell et al., 2005). Fortunately, union coverage is very constant over time whereas this is not the case for union density. Differences in union coverage are thus controlled for by industry fixed effects. The sources and some description of the data on union density and minimum wages are in the Data Appendix.
} 
Dependent Variable: $\log ($ wh/wl) based on three-year averages

Dependent Variable:

5-year averages

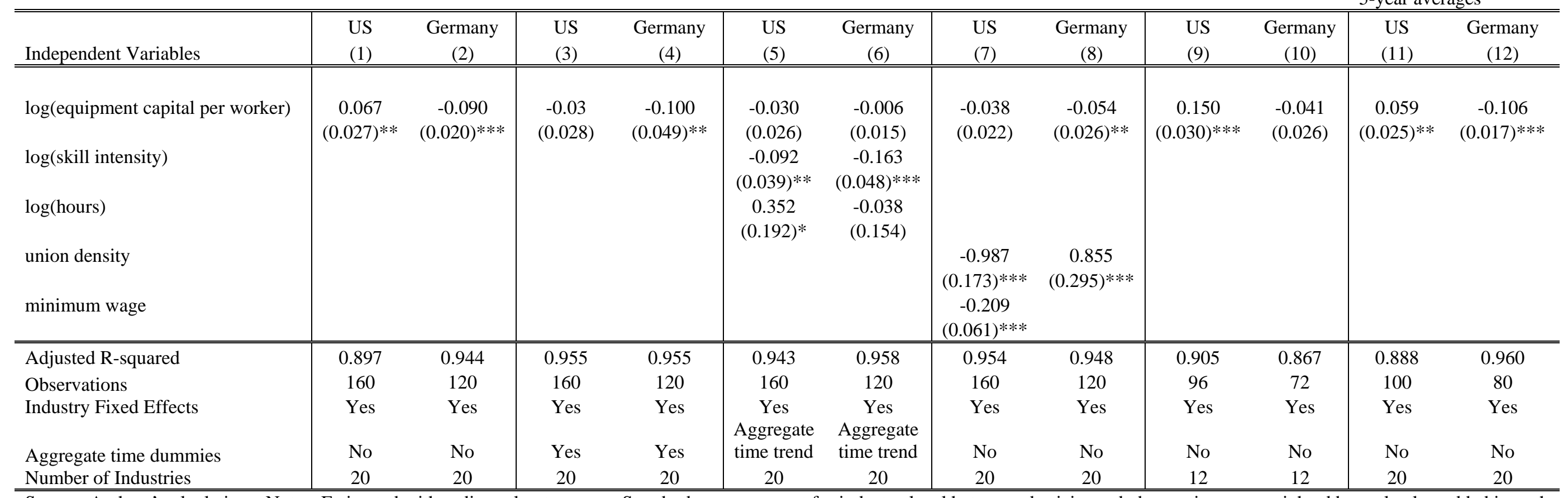

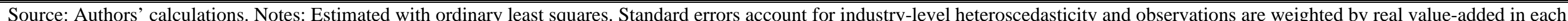

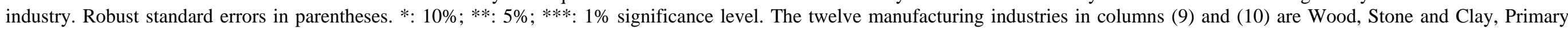

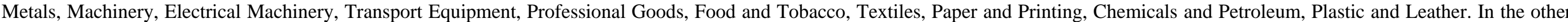

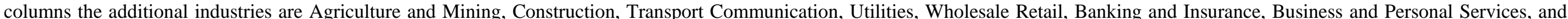
Health Services. See the Data Appendix for further details.

\section{Table 1. Estimation results for the wage differential as a function of capital equipment per worker with additional controls}


Skill intensity and institutions

We investigate further alternative sources of time variation rather than unobserved technology change. Thus, as a second step we check the robustness of the results towards changes in the skill intensity or institutions. Controlling for the skill intensity and the amount of hours worked, which both vary across industries and time, we also need to control for an aggregate time trend. Otherwise the skill intensity would be positively related to the wage differential in the US as is well known since this triggered the literature on skill-biased technology change (see Berman et al., 1998, and his references). We find that the elasticity of wage differentials with respect to the skill intensity is negative and significant for both countries if slightly more so for Germany. Hours worked are not relevant in both regressions. Most importantly, controlling for an aggregate time trend and skill intensity decreases the size and significance of the coefficients of capital equipment per worker. The point estimates are no longer significant for both the US and Germany. This is consistent with aggregate evidence of Acemoglu (2002, Table 2) for the US. We cannot be sure at this stage whether this result is due to measurement problems for capital per worker or really suggests that differences in the extent of skill-bias in the technology change in the US and Germany might explain this result. One alternative possibility for a different time trend in the US and West Germany are changes in labor market institutions and the resulting different incentives for investment into capital equipment. Of course, pure differences in technology change are also a possible explanation which we investigate further in Section 4.1.2.

We now want to investigate the role of institutional change in the US and Germany as another alternative source of aggregate time variation which might explain the different association between capital equipment and the wage differential. The decline of minimum wages and the union density in the US since the 1970s might explain why wage differentials have increased and the stock of capital equipment has risen.$^{18}$ On the one hand, weaker unions imply that workers appropriate a smaller share of the output after firms have made their capital investment so that firms have a stronger incentive to invest. Moreover, unions tend to compress the wage structure so that weaker unions might induce a higher wage differential. The problem with this explanation is that union density has declined in both Germany and the US during the sample period, if only very little in Germany. As can be seen in column (5), aggregate changes in union density and minimum wages reduce the size and the significance of the coefficient for capital equipment in the US. Both the decline of union density and the minimum wage during the sample period are strongly correlated with the increase in the wage differential in the US. For Germany, however, the decline in union density cannot explain the negative association between the wage differential and capital equipment. The coefficient for capital equipment remains negative and significant at the 5\% level. Moreover, the coefficient of union density has the wrong sign. The union density has declined very little and remained nearly constant as the wage differential so that the correlation is positive. Thus, time variation in institutions per se cannot fully explain the different relationship between capital equipment and the wage differential in the US and Germany. The much bigger variation of institutions across countries remains a plausible 
explanation.

Of course, it is important to emphasize that the institutional measures we use in the regressions are imperfect. For example, minimum wages do not exist in Germany during the sample period but only in the US, but wage compression by institutions in Germany is nonetheless more important because unions play a much stronger role.

\subsection{Robustness}

We probe the robustness of the results across two dimensions. Regarding the definition of the skill-wage differential $\left(w_{h} / w_{l}\right)$ we check robustness using four alternative measures for skills. Concerning the regressors, we construct two different measures for the capital stock and a measure for embodied $R \& D$ as proxy for process innovations.

\subsubsection{Robustness of wage measures}

Table 2 displays the results for four different measures of the skill-wage differential. As mentioned in Section 3, if we define skilled workers as those workers with some college education, we get much lower skill-intensities in Germany than in the US. Hence, we also construct two alternative skill measures for Germany. One can be considered an upper bound and includes all employees with a vocational degree in the skilled group. The results for wage differentials based on this skill measure are displayed in Table 2, column (1). The other skill measure only includes those workers with a vocational degree in the skilled group who are in a white-collar position. Results for regressions based on that skill measure are in Table 2, column (2).

We find that if we include workers with vocational degree in the skill group, this reduces the size and significance of the negative coefficient for capital equipment in Germany. For the second measure the coefficient even becomes positive and significant. The coefficient, however, remains significantly smaller than the coefficient for the US (see Table 1, column 1). Thus, the smaller effect of capital equipment on the wage differential in Germany than in the US is robust to these changes in the definition of skills.

It is not surprising to find a more positive coefficient of capital equipment if we define more medium-skilled workers as skilled rather than unskilled. The productivity of medium-skilled workers should be most affected if their wages are compressed from below and vocational training is complementary to heavier use of capital equipment. That is, these workers might have received some vocational training to operate capital equipment.

Of course, education is not necessarily a comprehensive measure of skills. As long as skills translate into higher productivity and wages, the wage distribution will reflect the 
distribution of skills. Thus, as a second robustness check, we classify individuals with a wage above the median as skilled and all individuals with a wage below the median as unskilled. The wage differential $w_{h} / w_{l}$ is then defined as the ratio of the arithmetic mean above and below the median. Using this measure of the wage differential in columns (3) and (4) of Table 2, we find that the difference of the coefficients of capital equipment in the US and Germany is qualitatively robust. Again, the coefficient becomes positive and significant in Germany but the coefficient is much smaller than in the US.

\section{College premium}

Finally, we improve our measure of the wage differential exploiting the information in the CPS and IAB micro data sets to control for differences in worker characteristics such as gender and experience across industries. The wage differential is obtained by regressing log wages on a dummy for education (at least some college in the US and Abitur or more in Germany) controlling for experience, experience squared, gender and their interactions. The regression is run for each industry and year in the CPS and IAB data, respectively. We then keep the coefficients of the education dummy as a measure of the college premium. We use the inverse of the standard errors to weigh each obtained estimate. Columns (5) and (6) in Table 2 show again a larger positive coefficient of capital equipment for the US than for Germany. Controlling for some observed worker heterogeneity across industries, however, reduces the difference by more than $50 \%$ compared with the benchmark specification in Table 1, columns (1) and (2).

Overall the smaller coefficient of capital equipment in Germany compared with the US is robust across regressions with wage differentials that are based on quite different skill measures. This gives us some confidence that the difficult comparison of skill measures for the US and Germany is not crucial for this result. Whether the coefficient is negative or positive for Germany, however, depends on the skill measure we use. 
Table 2. Robustness for different measures of the wage differential

Dependent Variable: $\log ($ wh/wl) based on three-year averages

\begin{tabular}{|c|c|c|c|c|c|c|}
\hline \multirow[b]{2}{*}{ Independent Variables } & \multicolumn{2}{|c|}{$\begin{array}{l}\text { Include vocationally } \\
\text { trained in skilled group } \\
\text { for Germany (two } \\
\text { alternative measures) } \\
\end{array}$} & \multicolumn{2}{|c|}{$\begin{array}{l}\text { Define skilled as those } \\
\text { with wages above the } \\
\text { median }\end{array}$} & \multicolumn{2}{|c|}{$\begin{array}{l}\text { College premium of } \\
\text { Mincer-type wage } \\
\text { regression }\end{array}$} \\
\hline & $\begin{array}{c}\text { Germany } \\
(1) \\
\end{array}$ & $\begin{array}{c}\text { Germany } \\
(2) \\
\end{array}$ & $\begin{array}{l}\text { US } \\
(3) \\
\end{array}$ & $\begin{array}{c}\text { Germany } \\
(4) \\
\end{array}$ & $\begin{array}{l}\text { US } \\
(5) \\
\end{array}$ & $\begin{array}{c}\text { Germany } \\
(6) \\
\end{array}$ \\
\hline log(equipment capital per worker) & $\begin{array}{c}-0.017 \\
(0.013)\end{array}$ & $\begin{array}{c}0.028 \\
(0.008)^{* * *}\end{array}$ & $\begin{array}{c}0.116 \\
(0.023)^{* * *}\end{array}$ & $\begin{array}{c}0.077 \\
(0.012)^{* * *}\end{array}$ & $\begin{array}{c}0.055 \\
(0.009)^{* * *}\end{array}$ & $\begin{array}{c}0.025 \\
(0.010)^{* *}\end{array}$ \\
\hline Adjusted R-squared & 0.963 & 0.975 & 0.882 & 0.955 & 0.850 & 0.955 \\
\hline Observations & 120 & 120 & 160 & 120 & 160 & 120 \\
\hline Industry Fixed Effects & Yes & Yes & Yes & Yes & Yes & Yes \\
\hline Aggregate time dummies & No & No & No & No & No & No \\
\hline Number of Industries & 20 & 20 & 20 & 20 & 20 & 20 \\
\hline
\end{tabular}

Source: Authors' calculations. Notes: Estimated with ordinary least squares. Robust standard errors account for industrylevel heteroscedasticity and observations are weighted by real value-added in each industry. Robust standard errors in parentheses. *: $10 \%$; **: 5\%; ***: $1 \%$ significance level. The Mincer-type wage regresion is run for each industry and year in the CPS and IAB, respectively. The regressors are education and experience, experience squared, gender and their interactions. The coefficients of the education dummy are a measure of the education wage differential after controlling for the other variables. We use the inverse of the standard errors to weight each obtained estimate. See the notes to Table 1 and the Data Appendix for further details. 


\subsubsection{Robustness of capital measures and embodied R\&D}

Table 3 displays the results for different measures of capital and embodied R\&D. Since capital measures are notoriously hard to deflate we first check the robustness of the benchmark specification in Table 1, columns (1) and (2), by applying the capital-price deflator provided by Cummins and Violante (2002). This deflator better controls for quality adjustments and updates the price deflator for capital equipment in the US constructed by Gordon (1990). Compared with the deflator of Cummins and Violante, the deflator of the Bureau of Economic Analysis underestimates quality improvements and thus results in higher price changes. We apply the deflator of Cummins and Violante, available for 1975-99, to our measure of capital in the US and Germany. The estimation results in Table 3, columns (1) and (2), show that both coefficients decrease in absolute size but remain highly significant, where the coefficient is positive for the US and negative for Germany.

\section{The RAS procedure}

The construction of internationally comparable capital stocks requires particular attention with respect to the use of: 1) comparable price deflators when constructing capital from investment series and 2) the use of comparable depreciation rates and lifetime periods for different equipment types.

We further investigate whether the different results for Germany are driven by compositional effects in terms of different equipment types. We use information from the German statistical office on capital formation for different equipment types to construct a time series for capital equipment by investment good and industry, applying the so-called RAS procedure (see the Data Appendix for a detailed description). This allows us to apply separate depreciation rates and price deflators for five different categories of equipment goods, before we aggregate the series at the industry level. This different construction of the stock of capital equipment implies a growth in the stock of capital equipment that is more than twice as high (see Sakellaris and Vijselaar, 2005, for similar results). Table 3, column (3), shows that the coefficient of capital equipment per worker remains negative for Germany for this new measure but the coefficient is less significant. In column (4), we only use the capital equipment for communication technology in Germany since we would expect a weaker complementarity of this type of equipment with unskilled workers. The coefficient is slightly less negative and significant at the $10 \%$ level. ${ }^{19}$

\section{Embodied R\&D}

As mentioned in Section 4.1, other sources of aggregate variation like technology change might induce a different correlation between capital equipment and wage differentials in the US and Germany. Approximating technology change with time trends, as done in Section 4.1, leaves much to be desired since it is unclear what the time trends really capture. Thus, we use R\&D as a more explicit measure for technology change. The measure of R\&D expenditure provided in the OECD

\footnotetext{
${ }^{19}$ Using the series for the other types of equipment, we do not find significant results. We also used the series on office machinery and computers for Germany constructed by Falk and Koebel (2004): the coefficient of capital equipment per worker and the corresponding standard error changes to $-0.027(0.014)$ which is significant at the $10 \%$ level. This coefficient is less negative than the coefficient of capital equipment in the benchmark specification of Table 1, column (2).
} 
STAN database captures expenses for all inputs (such as capital and labor) used for product as well as process innovations. The results in columns (5) and (6) show a positive coefficient for R\&D intensity in the US and a negative coefficient for Germany. Both coefficients are not significant.

An obvious criticism of the OECD measure is that this R\&D expenditure need not be related to technology improvements in the same industry and country. As an alternative measure we construct technology change embodied in one important input, capital equipment. Wilson (2002) combines data on R\&D expenditure for capital equipment goods provided by the National Science Foundation with data on capital equipment inputs by industry from the BEA for the years 19731997. This allows us to compute a measure of R\&D embodied in the capital equipment used in each industry which is more likely to capture process innovations. Assuming that the R\&D contained in capital goods is the same in the US and Germany, we use the different investment into capital equipment by good type and industry to construct the corresponding series for Germany. Columns (7) and (8) show that the coefficient for R\&D embodied in capital equipment is positive and highly significant for the US. The coefficient for Germany is negative but not significant.

Overall the results for alternative measures of capital equipment and embodied R\&D in capital equipment suggest that the difference in the association with the wage differentials in the US and Germany is very robust. The differences seem to stem from different types of capital investment in the US and Germany and thus also different technology improvements embodied in capital goods. We also experimented with firm-level measures for capital equipment and R\&D using Compustat data for the manufacturing sector in the US 1973-95 (see Hall et al., 2000). ${ }^{20}$ The results (which are not reported) remain qualitatively the same compared with the previous industry level regressions for the US.

\footnotetext{
${ }^{20}$ Unfortunately the Compustat Germany is only available for 1992-2001 with scarce information on R\&D and capital investment so that we cannot use this dataset to compare results with our West-German sample 1975-1991.
} 
Table 3. Robustness for different measures of capital and embodied R\&D

\begin{tabular}{|c|c|c|c|c|c|c|c|c|}
\hline \multirow[b]{3}{*}{ Independent Variables } & \multirow{2}{*}{\multicolumn{2}{|c|}{$\begin{array}{c}\text { Capital Equipment with } \\
\text { Cummins-Violante Deflator } \\
\end{array}$}} & \multicolumn{2}{|c|}{$\begin{array}{l}\text { Capital Equipment } \\
\text { (RAS procedure) }\end{array}$} & \multirow{2}{*}{\multicolumn{2}{|c|}{ R\&D OECD }} & \multirow{2}{*}{\multicolumn{2}{|c|}{ Embodied R\&D, Wilson }} \\
\hline & & & Total & $\begin{array}{c}\text { Commun } \\
\text { ication } \\
\end{array}$ & & & & \\
\hline & $\begin{array}{l}\text { US } \\
(1) \\
\end{array}$ & $\begin{array}{c}\text { Germany } \\
(2) \\
\end{array}$ & $\begin{array}{c}\text { Germany } \\
\text { (3) } \\
\end{array}$ & $\begin{array}{c}\text { Germany } \\
(4) \\
\end{array}$ & $\begin{array}{l}\text { US } \\
(7) \\
\end{array}$ & $\begin{array}{c}\text { Germany } \\
(8) \\
\end{array}$ & $\begin{array}{l}\text { US } \\
(9) \\
\end{array}$ & $\begin{array}{c}\text { Germany } \\
(10) \\
\end{array}$ \\
\hline log(equipment capital per worker) & $\begin{array}{c}0.050 \\
(0.017)^{* * *}\end{array}$ & $\begin{array}{c}-0.058 \\
(0.019)^{* * *}\end{array}$ & $\begin{array}{l}-0.029 \\
(0.022)\end{array}$ & $\begin{array}{c}-0.021 \\
(0.010)^{*}\end{array}$ & & & & \\
\hline $\log (\mathrm{R} \& \mathrm{D}$ / value added) & & & & & $\begin{array}{r}0.054 \\
(0.042) \\
\end{array}$ & $\begin{array}{l}-0.001 \\
(0.009) \\
\end{array}$ & $\begin{array}{c}0.063 \\
(0.009)^{* * *} \\
\end{array}$ & $\begin{array}{l}-0.031 \\
(0.021) \\
\end{array}$ \\
\hline Adjusted R-squared & 0.914 & 0.950 & 0.931 & 0.948 & 0.822 & 0.846 & 0.923 & 0.933 \\
\hline Observations & 160 & 120 & 120 & 106 & 96 & 72 & 160 & 120 \\
\hline Industry Fixed Effects & Yes & Yes & Yes & Yes & Yes & Yes & Yes & Yes \\
\hline Aggregate time dummies & No & No & No & No & No & No & No & No \\
\hline Number of Industries & 20 & 20 & 20 & 20 & 12 & 12 & 20 & 20 \\
\hline
\end{tabular}

Source: Authors' calculations. Notes: Estimated with ordinary least squares. Robust standard errors account for industry-level heteroscedasticity and observations are weighted by real value-added in each industry. Robust standard errors in parentheses. *: $10 \%$; **: 5\%; ***: $1 \%$ significance level. See the notes to Table 1 and the Data Appendix for further details. 


\section{DISCUSSION}

The empirical evidence presented above is consistent with our hypothesis that wagecompressing labor market institutions in Germany might have induced subsequent changes in capital equipment or embodied R\&D which in turn have increased the productivity of unskilled workers and reduced wage inequality. ${ }^{21}$ Of course, the available data do not allow us to interpret the different coefficient estimates as causal. ${ }^{22}$ Since the US and Germany differ across many dimensions, one main concern is that the correlations reflect changes of other omitted variables which might cause both changes in the wage differential and capital equipment or R\&D. For example, governments might not only regulate the labor market but also subsidize capital investment more in Germany. Our fixed effect estimates control for all time-invariant differences across countries and industries and in some of the specifications we also control for other sources of aggregate time variation. However, changes in unobserved variables that are not captured by these time dummies or linear trends could still render the correlation spurious.

We now relate our results further to the literature. We first investigate whether capital deepening in Germany is accompanied by a more adverse evolution of employment in Germany than in the US. We then discuss alternative explanations of the evidence before we emphasize the policy implications.

\subsection{Employment}

One obvious concern is that the different evolution of the skill-wage differential in Germany compared with the US is explained by the different evolution of the relative employment patterns. According to the well-known Krugman hypothesis skill-biased technology change induced a shift in relative labor demand which is borne out in a higher wage differential in the US. In Germany instead, wages for unskilled workers cannot fall to their market clearing level because of institutions. Thus, unemployment of unskilled workers increased relatively more. The Krugman hypothesis, however, is not borne out in the data. As emphasized by Nickell (1997, see also his references) and Krueger and Pischke (1998) employment rate changes for unskilled and skilled workers were almost the same in Germany. Although unemployment has risen more in Germany than in the US, this increase in unemployment has not been more concentrated among unskilled workers in Germany. The skill composition of the employed population has remained rather stable over time (see the discussion in Beaudry and Green, 2003, and

\footnotetext{
${ }^{21}$ In principle one could directly estimate a production possibility frontier for each industry to find out more about factor complementarities and biased technology change. Unfortunately, the data do not allow such estimation with enough precision.

${ }^{22}$ We experimented, for example, with using public R\&D expenditure as instrument for private $R \& D$. Unfortunately, the industry data on public R\&D provided by the OECD are very noisy. Although the correlation between both R\&D measures is significant at the $5 \%$ level in the first stage, the standard errors in the second-stage regression increase so that we do not find any significant results.
} 
their references). Thus, differences in employment patterns by skill cannot explain the different evolution of the wage differentials.

Although there is no strong evidence for differences in the composition of employment, aggregate employment growth has been stronger in the US than in Germany. One reason could be, as in our model, that institutions like unions or minimum wages increase the cost of labor for firms so that aggregate employment falls. Wage compression is no 'free lunch' so that firms are less willing to post vacancies, as shown more formally in the model in Appendix I. Hence, unemployment in Germany is predicted to be higher than in the US.

In order to investigate how much the differences in aggregate employment trends affect our results we run a counterfactual experiment: we apply the US employment growth rates to the German employment levels in 1975 for each industry. We then use this employment series to compute the counterfactual capital-labor ratio had Germany experienced the same employment performance as the US. Since the US has had a stronger employment performance than Germany, the counterfactual capital-labor ratio is smaller. Recall that the predicted values for the wage differential with the actual German capital-labor ratios imply a decrease of the wage differential of about $10-20 \%$ in most manufacturing industries (see Section 4.1. above). The predicted values for the wage differential using the counterfactual capital-labor ratio (holding the estimated coefficient constant), still imply a fall in the wage differential in Germany for 12 industries out of 20. The biggest effect of capital equipment per worker is still in the banking sector where changes in capital equipment per worker now imply a wage differential that is $37 \%$ lower, even if Germany had experienced the same employment growth as in the US. ${ }^{23}$

These results are similar to Beaudry and Green (2003) in that differences in the size of capital-labor ratio can explain some of the differences in the evolution of the wage differential. In our paper, however, we emphasize a different relationship between capital equipment and the wage differential because the different size and sign of the coefficient of capital equipment in the US and Germany suggests that the type of capital equipment might have been more complementary to unskilled workers in Germany.

\subsection{Alternative explanations}

As we mentioned above, differences in disembodied technology change across countries are an alternative explanation for the different co-variation of capital equipment and wage differentials. As in the aggregate evidence of Acemoglu (2002) for the US, ${ }^{24}$ adding a linear-time trend wipes out the significant differences between both countries.

\footnotetext{
${ }^{23}$ This relates to results of Beaudry and Green (2003) who find in a similar exercise that the education differential would have been 0.02 higher and wages of low educated $17 \%$ lower had Germany had the US employment miracle.

${ }^{24}$ Acemoglu (2002), Table 2, finds that, controlling for relative skill supply, a one percent fall of the relative price of capital equipment is associated with a $0.323 \%$ increase of the college premium in a regression without a time trend. With a time trend this number falls to $0.051 \%$. This is consistent with our findings if the ownprice elasticity of capital equipment is smaller than 1 .
} 
Differences in disembodied technology changes in both countries could arise because skills of workers in Germany are more specific than in the US. In a recent paper Krueger and Kumar (2004) argue that growth differences between the US and Europe can be explained by the higher degree of skill specificity in Europe. In their model, more vocational training hampers technology adoption and, if technology change is skillbiased, this implies that the wage differential increases less in Europe than in the US. Slower technology adoption per se, however, cannot explain a negative correlation between the wage differential and capital equipment or embodied R\&D in Germany which we find in some specifications. Moreover, the amount of vocational training might be related to wage compressing institutions, too, as firms can make workers more productive by giving them equipment and/or training them. To distinguish these two hypotheses further, one would need detailed data with a time series dimension and information on capital equipment and worker training.

A second possible alternative explanation would pose that wage differentials in Germany are compressed because labor market institutions imply not only wage floors but also wage ceilings. In the latter case, however, the skilled would be paid below their marginal product and firms would appropriate all productivity increases. Therefore capital investment and technology change should be directed more towards skilled workers in Germany. Moreover, wage floors are important since empirical evidence shows that the wages of the very unskilled workers have fallen in the US since the 1970s (see the discussion in Acemoglu, 2002) whereas this has not been the case in Germany. This does not exclude that additional distortions arise due to compression at the top of the wage distribution in Germany.

Finally, it could be the case that the larger increase of the capital-labor ratio in Germany compared with the US is driven by catching-up growth (see Figure 1). However, catchup growth cannot explain why this is accompanied with a decrease in the wage differential in Germany given that the level of the wage differential has been always lower than in the US and convergence in capital-labor ratios should imply convergence to the same wage differential, too. Furthermore, note that for equipment capital per worker, with all the caveats that comparisons in levels imply, the two countries seem to be diverging rather than converging at least for some industries (see Table A.1 and A.2).

\section{CONCLUSIONS AND POLICY IMPLICATIONS}

Capital deepening may affect the evolution of the wage differential between skilled and unskilled workers differently in countries with different labor market institutions. If labor market institutions raise the relative wage of unskilled workers in Germany, firms have incentives to invest relatively more into capital equipment complementary to unskilled workers. Instead in the US, where wage-compressing institutions are weaker, firms invest more in high-skilled workers.

We provide evidence consistent with this view based on an industry panel for West Germany and the US between the 1970s and 1990s. We show that capital equipment per worker is less positively associated with the wage differential in West Germany than in 
the US. This descriptive evidence is robust to many alternative measures for capital and skills.

Our evidence has several important policy implications. The first implication is that the debate on the role of institutions needs to consider the indirect effect of institutions on wage inequality through investment incentives. Our estimates imply that capital deepening in Germany in the 1980s is associated with a reduction in the wage differential of about $10-20 \%$ in most industries. In the US instead, capital deepening is associated with an increase of the wage differential between 5 and $15 \%$ in most industries. If we consider that (at least some) of this effect of capital is due to institutions, we have to reconsider the importance of institutions in the classic efficiencyequality trade-off. On the one hand institutions might have stronger effects on wage inequality than commonly perceived (if both the standard direct effect and the indirect effect through investment matter). On the other hand institutions distort investment decisions in favor of unskilled. Since the productivity increases for unskilled workers are no 'free lunch', the investment distortions are costly for firms (as are the wage constraints per se) and employment falls.

The second policy implication is that industries with low skill intensity in Germany will invest relatively more and will invest in more low-skill-complementary capital. Since some of the service sectors like banking and insurance, business, personal or health services are quite skill intensive, the different incentives for capital investment in Germany might also slow down the structural change from manufacturing towards services. Given that most of the employment growth occurs in the service sector, the implications for the evolution of unemployment, growth and structural change need also be considered (see, for example, Rogerson, 2005, and his references for the different structural transformation in Europe and the US).

Of course, our descriptive evidence is not conclusive: more detailed firm-level data is needed to shed further light on the mechanism of how and why firms invest in unskilled workers in countries with stronger wage-compressing institutions. This would also help to control further for changes in the composition of firms and workers over time.

\section{REFERENCES}

Abraham, K. and S. Houseman (1995). 'Earnings Inequality in Germany’, in: Freeman, R. B. and L.

F. Katz (eds.). Differences and Changes in Wage Structures. Chicago: The University of Chicago Press.

Acemoglu, D. (1996). 'A Microfoundation of Social Increasing Returns in Human Capital Accumulation’. Quarterly Journal of Economics, 111, 779-804

Acemoglu, D. (2002). 'Technical Change, Inequality, and the Labor Market', Journal of Economic Literature, 40, 7-72.

Acemoglu, D. (2003). ‘Cross-Country Inequality Trends', Economic Journal, 113, F121-49.

Acemoglu, D. and J.-S. Pischke (1999). 'The Structure of Wages and Investment in General Training’, Journal of Political Economy, 107, 539-72.

Autor, D., L. F. Katz and M. Kearney (2005): 'Trends in U.S. Wage Inequality: Re-Assessing the 
Revisionists’, NBER Working Paper. No. 11627.

Beaudry, P. and D. A. Green (2003). 'Wages and Employment in the United States and Germany: What Explains the Difference’, American Economic Review, 93, 573-602.

Berman, E., J. Bound and S. Machin (1998). 'Implications of Skill-Biased Technological Change: International Evidence’, Quarterly Journal of Economics, 113, 1245-79.

Blanchard, O. (1997). 'The Medium Run’, Brookings Papers of Economic Activity, 2, 89-157.

Blanchard, O. (2006). 'European Unemployment: the evolution of facts and ideas', Economic Policy, 21, 5-59.

Blau, F. D. and L. M. Kahn (1996). 'International Differences in Male Wage Inequality: institutions versus market forces', Journal of Political Economy, 104, 791-837.

Caballero, R. J. and M. L. Hammour (1998). 'The Macroeconomics of Specificity', Journal of Political Economy, 106, 724-67.

Cummins, J. and G. L. Violante (2002). 'Investment-Specific Technical Change in the United States (1947-2000): Measurement and Macroeconomic Consequences’, Review of Economic Dynamics, 5, 243-84.

Diamond, P., D. L. McFadden and M. Rodriguez (1978). 'Measurement of the Elasticity of Factor Substitution and Bias of Technical Change’, in: Fuss, M. and D. L. McFadden (eds.). Production Economics: A Dual Approach to Theory and Applications. Volume II: Applications of the Theory of Production. Amsterdam: North-Holland.

Ebbinghaus, B. and J. Visser (2000). Trade Unions in Western Europe since 1945, Macmillan.

Falk, M. and B. Koebel (2004). 'The Impact of Office Machinery, and Computer Capital on the Demand for Heterogeneous Labour’, Labour Economics, 11, 99-117.

Fitzenberger, B., A. Osikominu and R. Völter (2005). 'Imputation Rules to Improve the Education Variable in the IAB Employment Subsample’, ZEW Discussion Paper. No. 05-10.

Gordon, R. (1990). The Measurement of Durable Good Prices, Chicago: University of Chicago Press.

Hall, B. H., A. Jaffe and M. Trajtenberg (2000). 'Market Value and Patent Citations: a first look', NBER Working Paper. No. 7741.

Huber, E., C. Ragin, and J. D. Stephens (1997). Comparative Welfare States Data Set, Northwestern University and University of North Carolina.

Koeniger, W., M. Leonardi, and L. Nunziata (2004). 'Labour Market Institutions and Wage Inequality’, IZA Discussion Paper. No. 1291.

Krueger, A. B., and J.-S. Pischke (1998). 'Observations and Conjectures on the U.S. Employment Miracle’, in: Public GAAC Symposium: Labor Markets in the USA and Germany. Bonn: GermanAmerican Academic Council, 99-126.

Krueger, D. and K. B. Kumar (2004). 'Skill-Specific rather than General Education: a reason for US-Europe Growth Differences', Journal of Economic Growth, 9, 167-207.

Krusell, P., L. E. Ohanian, J.-V. Rios-Rull and G. L. Violante (2000). 'Capital-Skill Complementarity and Inequality: A Macroeconomic Analysis’, Econometrica, 68, 1029-53.

Machin, S. and J. van Reenen (1998). 'Technology and Changes in Skill Structure: Evidence from Seven OECD Countries’, Quarterly Journal of Economics, 113, 1215-44.

Nickell, S. (1997). 'Unemployment and Labor Market Rigidities: Europe versus North America', Journal of Economic Perspectives, 11, 55-74. 
Nickell, S., L. Nunziata and W. Ochel (2005). 'Unemployment in the OECD Since the 1960s. What Do We Know?’, Economic Journal, vol. 115, 1-27.

O'Mahony, M. and B. van Ark (2003). EU Productivity and Competitiveness: An Industry Perspective. Can Europe Resume the Catching Up Process?. Luxemburg: Office for Official Publications of the European Communities.

Pischke, J.-S. (2005). 'Labor Market Institutions, Wages and Investment: Review and Implications', CESifo Economic Studies, 51, 47-75.

Pissarides, C. (2000). Equilibrium Unemployment Theory, second edition. Cambridge

(Massachusetts): MIT Press.

Rogerson, R. (2005). 'Structural Transformation and the Deterioration of European Labor Market Outcomes’, Arizona State University, mimeo.

Sakellaris, P. and F. Vijselaar (2005). 'Capital Quality Improvement and the Sources of Economic Growth in the Euro Area', Economic Policy, 20, 267-306.

Steiner, V. and K. Wagner (1998). 'Has Earnings Inequality in Germany Changed in the 1980's?', Zeitschrift für Wirtschafts- und Sozialwissenschaften, vol. 118, 29-59.

Visser, J. (1996). Unionisation Trends: The OECD Countries Union Membership File, University of Amsterdam, Centre for Research of European Societies and Labour Relations.

Wilson, D. J. (2002). 'Is Embodied Technology the Result of Upstream R\&D? Industry-Level Evidence', Review of Economic Dynamics, 5, 285-317.

\section{Appendix I: Theoretical background}

In this Appendix we show more formally, how labor market institutions can rationalize the different association of wage differentials and capital investment in the US and Germany. In the model, institutions that induce a lower bound on wages, like a minimum wage, increase the incentive for capital investment related to less skilled workers. Since capital increases the productivity of workers, this explains why more capital investment in Germany does not increase wage differentials as much as in the US, where wages are flexibly set. We derive how these predictions depend on the model parameters in an intuitive way.

\section{Model set-up}

We frame our analysis in the model proposed by Acemoglu (2003) whose structure we repeat for completeness. We refer the interested reader to his paper for a more detailed discussion of the assumptions. ${ }^{25}$ Maybe the most important assumption in this model for our results is that labor markets are imperfect. This assumption implies that there are quasi-rents which allow (i) firms to survive even if minimum wages constrain their choices and (ii) wages of the same type of worker to differ in equilibrium. We allow workers to differ with respect to their skill-type. We assume that a fraction $\phi$ of workers has skill $h_{s}$ and a fraction $1-\phi$ has skill $h_{u}$, where $h_{u}<h_{s}$. The supply of both

\footnotetext{
${ }^{25}$ Acemoglu (2003) focuses on the effect of more expensive investment whereas we analyze the effect of cheaper capital investment. We show that his predictions for wage differentials also hold for falling prices of capital investment, which is consistent with the data we use for Germany and the US. The fall of the price of capital by itself implies a fall of unemployment.
} 
workers is inelastic. We assume further that unfilled vacancies are homogenous. When these vacancies have been filled, firms decide about capital investment.

Technology. The production technology is linear in skills $A h$. Firms can also invest into a more productive technology $(1+\alpha) A h$ at the cost $p_{k}$, where $\alpha>0$. This can be interpreted as investment into capital equipment which makes workers more productive or any other change in technology which increases labor productivity. Note that new technologies are complementary to skills since $1+\alpha$ is multiplied by $h$. If the new technology is adopted for both skilled and unskilled workers, however, the wage differential remains unchanged. The latter is not important and could be relaxed by letting the productivity improvement be a non-linear function $\alpha(h)$, for example with $\alpha^{\prime}(h)>0$.

The labor market. The labor market is modeled as in a standard search-andmatching model with undirected search (see, for example, Pissarides, 2000). Costly search prevents the labor market to clear and implies equilibrium unemployment. Firms post a total number of vacancies $V$ which are matched to mass of unemployed workers $U$ with probability $q(\theta)$, where $\theta \equiv V / U$ and we assume that the matching function has constant returns to scale. Unemployed workers find a job with probability $\theta q(\theta)$. Each firm-worker match is destroyed with exogenous probability $S$. Finally, the timing assumption is that the firm decides whether to invest only after the vacancy has been matched to a worker.

Wage determination. As in Acemoglu (2003), wages are assumed to equal the fraction $\beta$ of the worker's actual production, $w(x, h)=\beta(1+\alpha x) A h$, where $x=1$ if the firm decides to adopt the new technology and $x=0$ otherwise. Note that wages are negotiated after the technology investment is sunk. Furthermore, the wage-setting rule would result from a bargaining game if the fraction of unmatched agents after each round of the bargaining game approaches zero (see Acemoglu, 1996). The solution is similar to the one obtained from the standard Nash-bargaining problem if we fix the outside option of workers at zero. Otherwise there would be an additional term in the wage expression, $(1-\beta) r W^{U}(\theta)$, where $W^{U}$ is the asset value of an unemployed worker. By neglecting this term, we abstract from equilibrium effects, which result from changes of the outside option, and their effect on wages. Since $\partial W^{U}(\theta) / \partial \theta>0$, higher unemployment rates (as for Germany compared with the US below) would lower the outside option and thus wages. These equilibrium effects are not important for the qualitative results derived below, and thus we first stick to the formulation in Acemoglu (2003) for simplicity. We relax this assumption below where we allow for equilibrium effects.

Asset value of the filled and unfilled vacancy. For small time intervals, in the steady state the asset value of the filled vacancy, $J^{E}$, reads

$$
r J^{E}(x, h)=A h+x\left(\alpha A h-p_{k}\right)-w(x, h)+s\left(J^{V}(x, h)-J^{E}(x, h)\right),
$$

where $J^{V}$ is the asset value of an unfilled vacancy. If posting a vacancy costs $\gamma$, the value of $J^{V}$ is given by 


$$
\begin{aligned}
r J^{V}(x, h)= & -\gamma+q(\theta)\left\{\phi \max \left[J^{E}\left(1, h_{s}\right) ; J^{E}\left(0, h_{s}\right)\right]+(1-\phi) \max \left[J^{E}\left(1, h_{u}\right) ; J^{E}\left(0, h_{u}\right)\right]\right\} \\
& -q(\theta) \max \left[J^{V}(x, h) ; 0\right] .
\end{aligned}
$$

Free entry implies $J^{V}=0$ so that rearranging both asset-value equations (substituting the wage) gives

$$
(r+s) J^{E}(x, h)=(1-\beta)(1+\alpha x) A h-x p_{k}
$$

and

$$
\begin{aligned}
0=-\gamma & +q(\theta) \frac{\phi}{r+s}\left((1-\beta) A h_{s}+\max \left[(1-\beta) \alpha A h_{s}-p_{k} ; 0\right]\right) \\
& +q(\theta) \frac{1-\phi}{r+s}\left((1-\beta) A h_{u}+\max \left[(1-\beta) \alpha A h_{u}-p_{k} ; 0\right]\right) .
\end{aligned}
$$

Equilibrium. The free entry condition (A1) determines a unique $\theta$ for a given unemployment rate $u$. The unemployment rate is determined equating steady-state flows into and out of unemployment, $(1-u) s=\theta q(\theta) u$, so that

$$
u=\frac{s}{s+\theta q(\theta)}
$$

Both equations (A1) and (A2) can be solved for the unique equilibrium $(\theta, u)$. Note that the unemployment rate for skilled and unskilled workers is the same since, for simplicity, we assume random matching and a homogenous labor market.

We now proceed to analyze wage differentials and the unemployment rate and how they change if prices for capital investment decrease. We do this for two countries: the US, with flexible wages, and Germany, with a minimum wage.

\section{The wage differential and unemployment before capital cheapening in the}

\section{US}

We assume that, initially, new technologies are too expensive to adopt, independent of whether a vacancy is matched with a skilled or unskilled worker. That is

$$
(1-\beta) \alpha A h_{j}<p_{k}
$$

for $j=s, u$. Denoting the wage of a skilled worker as $w_{s}$ and the wage of an unskilled worker as $w_{u}$, the wage differential is then

$$
\left(\frac{w_{s}}{w_{u}}\right)_{U S}^{\text {pre }}=\frac{h_{s}}{h_{u}},
$$

where the superscript pre denotes the equilibrium before the cheapening of capital. 
The unemployment rate $u\left(\theta_{U S}^{\text {pre }}\right)$ is determined once we have solved for $\theta_{U S}^{\text {pre }}$ in the free-entry condition

$$
0=-\gamma+\frac{q\left(\theta_{U S}^{\text {pre }}\right)}{r+s}\left(\phi(1-\beta) A h_{s}+(1-\phi)(1-\beta) A h_{u}\right) .
$$

The wage differential and unemployment after capital cheapening in the US

Now, assume that the price for capital equipment falls, $p^{\prime}{ }_{k}<p_{k}$, so that

$(1-\beta) \alpha A h_{s}>p^{\prime}{ }_{k}$. Capital investment becomes optimal if the vacancy is matched with a skilled worker. However, the price of capital investment does not fall so much that capital investment is optimal for vacancies matched with unskilled workers, $(1-\beta) \alpha A h_{u}<p^{\prime}{ }_{k}$, so that the wage differential increases to

$$
\left(\frac{w_{s}}{w_{u}}\right)_{U S}^{\text {post }}=(1+\alpha) \frac{h_{s}}{h_{u}} \text {, }
$$

where the superscript post denotes the equilibrium after the cheapening of capital.

Labor market tightness $\theta_{U S}^{\text {post }}$ is given by

$$
0=-\gamma+\frac{q\left(\theta_{U S}^{\text {post }}\right)}{r+s}\left(\phi\left((1-\beta)(1+\alpha) A h_{s}-p_{k}^{\prime}\right)+(1-\phi)(1-\beta) A h_{u}\right) \text {. }
$$

Since the term in brackets increases and $q(\theta)$ is a decreasing function of $\theta$, the free entry condition implies that $\theta_{U S}^{\text {post }}>\theta_{U S}^{\text {pre }}$. Thus, the unemployment rate falls (the term $\theta q(\theta)$ in the denominator of the unemployment-rate equation (A2) increases in $\theta$ ).

Note that the wage differential would not increase if the price of capital fell so much that the technology would be adopted for vacancies matched to unskilled workers. This is because the productivity increase is linear in $h$. If $\alpha(h)$ with $\alpha^{\prime}(h)>0$, the wage differential also increases if capital is invested into all vacancies independent of the worker type.

The wage differential and unemployment before capital cheapening in

\section{Germany}

We assume that in Germany, wages cannot fall below $\underline{w}$ because union bargaining induces this (implicit) minimum wage. This implies that wages are determined by

$$
w(x, h)=\max [\beta(1+\alpha x) A h ; \underline{w}] .
$$

We assume that the minimum wage is not binding for skilled workers,

$$
\beta A h_{s}>\underline{w} \text {, }
$$

whereas the minimum wage is binding for unskilled workers unless capital investment increases their productivity:

$$
\beta(1+\alpha) A h_{u}>\underline{w}>\beta A h_{u} .
$$


Thus, capital is invested into vacancies that are filled with unskilled workers if

$$
J^{E}\left(1, h_{u}\right)-J^{E}\left(0, h_{u}\right)=(1-\beta)(1+\alpha) A h_{u}-p_{k}-A h_{u}+\underline{w}>0
$$

or

$$
(1-\beta) \alpha A h_{u}-p_{k}>\beta A h_{u}-\underline{w} .
$$

Since $\beta A h_{u}-\underline{w}<0$, if the minimum wage is binding, this inequality is more likely to hold than in the unconstrained case (where the right-hand side equals zero). The minimum wage makes the firm the residual claimant of additional productivity increases which stimulates productivity enhancing capital investment.

Let us assume as before, that prices for capital investment are so high initially that matched vacancies are never invested in. Then, the wage differential is

$$
\left(\frac{w_{s}}{w_{u}}\right)_{\text {GER }}^{\text {pre }}=\frac{\beta A h_{s}}{\underline{w}}<\left(\frac{w_{s}}{w_{u}}\right)_{U S}^{\text {pre }},
$$

if the minimum wage is binding. Labor market tightness $\theta_{G E R}^{\text {pre }}$ is given by

$$
0=-\gamma+\frac{q\left(\theta_{G R R}^{p r e}\right)}{r+s}\left(\phi(1-\beta) A h_{s}+(1-\phi)\left(A h_{u}-\underline{w}\right)\right) \text {. }
$$

Since $A h_{u}-\underline{w}<0, \theta_{U S}^{\text {pre }}>\theta_{G E R}^{\text {pre }}$ and the unemployment rate is higher in Germany than in the US before capital cheapening takes place.

\section{The wage differential and unemployment after capital cheapening in Germany}

Now, assume again that the price for capital equipment falls, $p_{k}^{\prime}<p_{k}$, so that $(1-\beta) \alpha A h_{s}>p^{\prime}{ }_{k}$ and $(1-\beta) \alpha A h_{u}<p^{\prime}{ }_{k}$. The interesting case is now when

$$
0>(1-\beta) \alpha A h_{u}-p^{\prime}{ }_{k}>\beta A h_{u}-\underline{w} .
$$

That is, without minimum wages capital would not be invested into vacancies that are matched with unskilled workers. Here we assume that the minimum wage is no longer binding after capital is invested. Otherwise the inequality collapses to $\alpha A h_{u}-p^{\prime}{ }_{k}>0$. The firm appropriates all productivity gains so that the fraction $\beta$ no longer enters in the equation compared with the US above.

Minimum wages create an additional incentive to invest into capital to make unskilled workers more productive and alleviate the minimum wage constraint. In this case, the wage differential is

$$
\left(\frac{w_{s}}{w_{u}}\right)_{\text {GER }}^{\text {post }}=\frac{h_{s}}{h_{u}}=\left(\frac{w_{s}}{w_{u}}\right)_{U S}^{\text {pre }}<\left(\frac{w_{s}}{w_{u}}\right)_{U S}^{\text {post }} \text {. }
$$

Moreover, the wage differential increases more in the US than in Germany: 


$$
\left(\frac{w_{s}}{w_{u}}\right)_{G E R}^{\text {post }} /\left(\frac{w_{s}}{w_{u}}\right)_{G E R}^{\text {pre }}=\frac{\underline{w}}{\beta A h_{u}}<1+\alpha=\left(\frac{w_{s}}{w_{u}}\right)_{U S}^{\text {post }} /\left(\frac{w_{s}}{w_{u}}\right)_{U S}^{\text {pre }},
$$

where the inequality follows from the assumption $\beta(1+\alpha) A h_{u}>\underline{w}>\beta A h_{u}$.

Of course, the investment into vacancies induced by the minimum wage is costly and has a negative effect on vacancy creation:

$$
0=-\gamma+\frac{q\left(\theta_{G E R}^{\text {post }}\right)}{r+s}\left((1-\beta)(1+\alpha)\left(\phi A h_{s}+(1-\phi) A h_{u}\right)-p_{k}\right) .
$$

Since $(1-\beta) \alpha A h_{u}<p_{k}, \theta_{U S}^{\text {post }}>\theta_{G E R}^{\text {post }}$ so that unemployment is higher in Germany than in the US after the capital cheapening, but unemployment falls in both countries. To summarize, the cheapening of capital increases the wage differential and lowers unemployment, but this effect is less pronounced in Germany than in the US.

\section{Alternative wage determination}

We now extend our model to allow for equilibrium effects on wages through changes in the outside option. For this we need to define the standard asset value of unemployed workers $W^{U}$ and employed workers $W^{E}$, where

$$
r W^{E}=w+s\left(W^{U}-W^{E}\right)
$$

and

$$
r W^{U}=b+\theta q(\theta)\left(W^{E}-W^{U}\right) \text {. }
$$

The flow value derived from leisure during unemployment is denoted by $b, s$ is the exogenous separation rate and $\theta q(\theta)$ is the job-finding rate of unemployed workers. These two equations can be solved for $W^{U}$ and $W^{E}$ so that

$$
r W^{E}=\frac{s b+(r+\theta q(\theta)) w}{r+s+\theta q(\theta)}
$$

and

$$
r W^{U}=\frac{(r+s) b+\theta q(\theta) w}{r+s+\theta q(\theta)} .
$$

We now assume that wages are determined by

$$
w(x, h, \theta)=\beta(1+\alpha x) A h+(1-\beta) r W^{U}(\theta),
$$

where $x=1$ if the firm decides to invest and $x=0$ otherwise. This is the wellknown solution for the wage in standard Nash-bargaining problem (see, for example, Pissarides, 2000). Plugging (A3) into (A4) and rearranging we get

$$
w(x, h, \theta)=\beta \frac{(r+s+\theta q(\theta))(1+\alpha x) A h}{r+s+\beta \theta q(\theta)}+(1-\beta) \frac{(r+s) b}{r+s+\beta \theta q(\theta)} .
$$


It is easy to show that the wage is an increasing function of $\theta$ for $(1+\alpha x) A h>b$. Note, however, that for $b=0$ the wage differential is independent of $\theta$ if the minimum wage is not binding. Thus, in this special case, the wage differentials for the US derived in the previous section apply.

As before, free entry implies that the value of a filled vacancy is

$$
(r+s) J^{E}(x, h)=(1+\alpha x) A h-x p_{k}-w(x, h, \theta) .
$$

The free entry condition then determines the equilibrium value of $\theta$ :

$$
0=-\gamma+q(\theta)\left\{\begin{array}{l}
\phi \max \left[J^{E}\left(1, h_{s}\right) ; J^{E}\left(0, h_{s}\right)\right] \\
+(1-\phi) \max \left[J^{E}\left(1, h_{u}\right) ; J^{E}\left(0, h_{u}\right)\right]
\end{array}\right\} .
$$

The unique equilibrium ( $w, \theta, u)$ is determined by equations (A1), (A5) and (A6). The qualitative results of the simpler model for the different evolution of the skill-wage differential in the US and Germany can also be generated with this extended version.

\section{Appendix II: Data description}

Industry classifications of the data series are summarized in Tables A3 and A4.

\section{Data for the US}

We use the Current Population Survey May in the period 1973-78 and May/ORG in the period 1979-2002 for data on wages and employment by skill and sector for each year. Our sample includes wage-and-salary workers in full-time employment, age 20-60 with potential labor market experience up to 39 years.

\section{Skill measure}

We define skilled workers as those with some college or college degree and all those with less education as unskilled.

\section{Wages}

Hourly wages are the logarithm of hourly earnings for those paid by the hour and the logarithm of usual weekly earnings divided by hours worked last week for workers not paid by the hour. Top-coded earnings are multiplied by 1.5. Full-time earnings below $\$ 67 /$ week in $1982 \$$ and hourly earnings below $\$ 1.675 /$ hour in $1982 \$$ are dropped as are hourly wages exceeding $1 / 35$ th of the top-coded value of weekly earnings. All earnings are deflated by the CPI. Allocated earnings are excluded in all years. Our final measure uses yearly wages which are comparable with the stock of capital computed on a yearly basis. Annual wages are obtained by multiplying hourly wages with hours worked last week times 52. For more details see Autor, Katz and Kearney (2005). The wage differential is then computed as the average wage of skilled workers over the average wage of unskilled workers by industry and year.

\section{Hours}

The data on hours by industry are taken from the 60-Industry Database, Groningen Growth and Development Centre, February 2005, http://www.ggdc.net. Since the data are only available 1979-2002, we extrapolate the early years 1973-78 in the sample 
based on the industry-specific linear time trend.

\section{Value added}

Since the BEA changed its industry-classification in 1998 in a way that makes it impossible to construct a consistent time series, we use the data on value added by industry from the 60-Industry Database, Groningen Growth and Development Centre, February 2005, http://www.ggdc.net for the time period 1979-2002 (see also O’Mahony and van Ark, 2003).

\section{Employment}

Employment by skill in each sector and year is given by the sum of employed persons in the CPS using the frequency weights to retrieve the total number in the population. We multiply both skilled and unskilled employment with the total numbers of hours worked per industry and year.

\section{Capital stock and gross capital formation}

We use the current cost net stock of private equipment and software by industry provided by the BEA (Table 3.1B). The series can be deflated using the chain-type quantity index provided by the BEA (Table 3.2B). We also use an alternative deflator which has been proposed by Gordon (1990) and has been updated by Cummins and Violante (2002). Data are available from 1975-99 since the series has a break in 1973/74. We use the price index available at the industry level. See the references above for further description on the construction of the price index.

\section{R\&D expenditure}

We use the R\&D data provided in the STAN-Anberd database for the years 1973-2000. Alternatively, we construct a measure for embodied R\&D by industry based on data from Wilson (2002). His measure combines data on R\&D expenditure by capital equipment provided by the NSF with data on capital equipment inputs by industry provided by the BEA. The rate of embodied technical change for each industry is defined as the weighted average of the R\&D expenditure directed to each of the 13 goods. The underlying assumption is that the technical change embodied in each good is proportional to the expenditure on $\mathrm{R} \& \mathrm{D}$. The weights for each industry are the share of investment into the respective equipment good. We divide R\&D expenditure with value added. Data are available until 1997 and are further explained in Wilson (2002).

\section{Net Union Density}

This variable is constructed as the ratio of total reported union members (gross minus retired and unemployed members), as reported in Visser (1996), over the number of wage and salaried employees, reported in Huber et al. (1997). The data are updated using data from the Bureau of Labor Statistics (1994 and 1995).

\section{Minimum Wage}

This is the ratio of the statutory minimum wage to the median wage. The data are provided by the OECD.

\section{Data for West-Germany}

We use a 1\% random sample of the social security records provided by the Institut für Arbeits- und Berufsforschung (IAB) in the period 1975-95 for data on wages and 
employment by skill and sector for each year. Our sample includes employees in fulltime employment, age 20-60 with potential labor market experience up to 39 years.

\section{Skill measure}

We define skilled workers as those with Abitur (high-school degree) and more education. Unskilled workers are those with less education than Abitur. An Abiturdegree implies usually 13 years of schooling which is comparable with some college in the US (which implies 13 or more years of schooling).

However, the education system in the US and Germany is quite different. College education is not as prevalent in Germany as in the US since vocational training has a much more important role in the German two-tier education system. Approximately $60 \%$ of the working population in Germany between 1975-91 had only a vocational degree.

Thus, the measure constructed above results in a much lower skill ratio in Germany than in the US. If we define skilled workers in Germany including all workers with vocational training, the skill ratio increases substantially and is higher in Germany than in the US (see Table A.2). Thus, we construct also another measure where we only include in the skilled group those workers with vocational degree who are in a white-collar position (Angestellter). These vocational degrees should be most comparable to college education in the US. With this skill measure the resulting skill-ratios for Germany and the US are similar (see Table A.2).

\section{Wages}

We only use the information on West-Germany in the IAB and drop all East-German observations after 1990. The IAB dataset is the only possibility to compute wage differentials by industry for our sample period (the German Socio-Economic Panel only starts in the second half of the 1980s, has a substantially smaller sample size and selfreported earnings information). The IAB data do not contain precise information on weeks or hours worked so that we keep records for regular full-time employment. The wage differential is computed as the average wage of skilled workers over the average wage of unskilled workers by industry and year. This measure is not without problems for two reasons (see Steiner and Wagner, 1998). Firstly, fringe benefits are included only since 1984 and cannot be distinguished. These benefits are likely to be more important for skilled workers. Secondly, earnings are right-censored at the amount of earnings for which social security contributions have to be paid. This matters for about $10 \%$ of the sample but much more for skilled workers. Whereas the first measurement problem should induce an upward bias of changes in the wage differential around 1984, the second measurement problem induces a downward bias. We have included a dummy for 1984 in our estimations for Germany without finding that the results change. Moreover, the smaller coefficient of capital equipment (in the regressions for Germany compared with the US) is robust to using quite different definitions of the wage differential in terms of skill groups for which the measurement problems are more or less of an issue (see Table 2 in the main text).

\section{Hours}

The data on hours by industry is taken from the 60-Industry Database, Groningen Growth and Development Centre, February 2005, http://www.ggdc.net. Since the data 
for West Germany are only available 1979-2002, we extrapolate the early years 1975-78 in the sample based on the industry-specific linear time trend.

\section{Value added}

We use the gross valued added (Bruttowertschöpfung) by industry and year in current prices and prices of 1995. The series are provided by the Statistisches Bundesamt (German Statistical Office) for Germany until 1991 (Tables 3.2.1 and 3.2.2).

\section{Employment}

We compute the fraction of skilled and unskilled workers by industry and year in the IAB. Since the IAB only contains employees with social security records, we scale up the number of employees to the total population using the series on total employment by industry and year provided by the Statistisches Bundesamt (Table 3.2.12).

\section{Capital stock and gross capital formation}

We use the gross capital formation on equipment (Ausrüstung) by industry and year from the Statistisches Bundesamt for Germany until 1995 (Table 2.1.2). The series exist for West Germany only until 1991. The real formation is in prices of 1991 deflated by a chain-type price index (Table 2.2.2). We accumulate this series using a perpetual inventory method. We assume a depreciation rate of $8.4 \%$ for all industries as in Machin and van Reenen (1998). Alternatively, we use the series on depreciation rates of equipment by industry. We use the current-cost depreciation for equipment provided by the Statistisches Bundesamt for West Germany until 1995 (this table is available upon request at the statistical office and called Abschreibungen in jeweiligen Preisen, Anlagen), divided by the net capital stock in current cost. All our results reported in the paper are robust to using the latter series.

We further check the robustness of our results applying the US deflator of Cummins and Violante (2002) for capital equipment also for Germany.

\section{Capital stock constructed with the RAS procedure}

We construct another measure of the capital stock in Germany exploiting disaggregate information on investment by equipment type. Since we can use information on only five good categories, this measure has the disadvantage that it is not necessarily representative for the total capital stock. The advantage is that we can construct the capital stock using depreciation rates and deflators which make this measure more comparable to the US measure. The US capital stock from the BEA is depreciated taking into account the varying composition of capital equipment. Each type of capital equipment has its own life-time and depreciation rate.

We use the table of total investment by equipment type for the whole German economy (Table 4.2) and the table for equipment investment by industry (Table 2.1.2), both provided by the Statistisches Bundesamt. The RAS procedure allows us to recover a matrix A of capital equipment investment by equipment type and industry (see Sakellaris and Vijselaar, 2005). In this procedure the matrix $\mathrm{R}$ is defined as investment aggregated for the five equipment types for which we have a separate price deflator (communication equipment, software, transportation equipment, information equipment and other equipment). The matrix $\mathrm{S}$ is investment by industry. As starting values for the matrix $\mathrm{A}$ we use the investment by equipment type and industry for the Euro area as computed by 
Sakellaris and Vijselaar (2005). The RAS procedure then allows us to iterate until convergence to recover the matrix A. We apply this procedure for each year, that is the matrices $\mathrm{R}$ and $\mathrm{S}$ and the starting values for A vary across years. The final output is a set of time series of capital equipment investment by type and industry. These can be accumulated into capital stocks using type-specific life-time periods and depreciation rates. The respective depreciation rates and life-times for the five equipment types are: 0.15 and 11 years for communication equipment, 0.4435 and 5 years for software, 0.115 and 15 years for transportation equipment, 0.254 and 8 years for information equipment, 0.1319 and 13 years for other equipment (see Sakellaris and Vijselaar, 2005). The time series of capital equipment for each industry is then constructed adding up the capital equipment types for each industry and year.

\section{R\&D expenditure}

We use the R\&D data for West Germany provided in the STAN-Anberd database for the years 1973-1993, interpolated for some missing years. The R\&D embodied in capital investment is computed analogous as for the US. We take the R\&D expenditure directed to capital goods for the US deflated by value added (since data are not available for Germany) and combine them with the German data we constructed for investment by equipment and industry using the RAS-procedure. The implicit assumption is that R\&D embodied in each type of equipment good is the same in the US and Germany but the type of equipment investment differs across the two countries. Due to data availability we only use 5 types of equipment goods for Germany compared with 13 goods for the US.

\section{Net Union Density}

The data are reported in Ebbinghaus and Visser (2000) using the same criteria as for the US. 
Table A.1. Summary statistics for the US

\begin{tabular}{|c|c|c|c|c|c|c|c|c|}
\hline Sector name & $\begin{array}{c}H / L \\
1970 \mathrm{~s} \\
\end{array}$ & $\begin{array}{c}\text { 1st diff. } \ln (H / L) \\
\text { 1980s-1970s } \\
\end{array}$ & $\begin{array}{c}\text { 1st diff. } \ln (H / L) \\
\text { 1990s-1980s } \\
\end{array}$ & $\begin{array}{l}w h / w l \\
1970 \mathrm{~s} \\
\end{array}$ & $\begin{array}{c}\text { 1st diff. } \\
\ln (\mathrm{wh} / \mathrm{wl}) \\
1980 \mathrm{~s}-1970 \mathrm{~s}\end{array}$ & $\begin{array}{c}\text { 1st diff. } \\
\ln (w h / w l) \\
1990 s-1980 \mathrm{~s}\end{array}$ & $\begin{array}{c}\text { 1st diff. } \ln \text { (hours) } \\
\text { 1980s-1970s } \\
\end{array}$ & $\begin{array}{c}\text { 1st diff. } \ln \text { (hours) } \\
\text { 1990s-1980s } \\
\end{array}$ \\
\hline Agriculture and Mining & 0.513 & 0.267 & 0.217 & 1.274 & 0.081 & 0.020 & -0.051 & -0.030 \\
\hline Construction & 0.334 & 0.121 & 0.377 & 1.158 & 0.071 & 0.035 & -0.004 & 0.022 \\
\hline Wood & 0.211 & 0.197 & 0.399 & 1.419 & 0.056 & -0.018 & 0.004 & 0.017 \\
\hline Stone, Clay etc. & 0.272 & 0.264 & 0.431 & 1.397 & 0.059 & -0.003 & 0.013 & 0.025 \\
\hline Primary Metals & 0.326 & 0.114 & 0.540 & 1.270 & 0.083 & 0.051 & 0.010 & 0.055 \\
\hline Machinery & 0.525 & 0.334 & 0.430 & 1.359 & 0.121 & 0.049 & -0.002 & 0.026 \\
\hline Electrical Machinery & 0.509 & 0.344 & 0.588 & 1.584 & 0.096 & 0.064 & 0.001 & 0.016 \\
\hline Transport Equipment & 0.447 & 0.398 & 0.474 & 1.323 & 0.072 & 0.070 & 0.020 & 0.020 \\
\hline Professional Goods & 0.553 & 0.492 & 0.553 & 1.717 & -0.026 & 0.062 & 0.000 & 0.011 \\
\hline Food and Tobacco & 0.332 & 0.112 & 0.373 & 1.340 & 0.098 & 0.076 & 0.000 & 0.029 \\
\hline Textiles & 0.143 & 0.305 & 0.583 & 1.899 & 0.010 & -0.017 & 0.006 & 0.016 \\
\hline Paper and Printing & 0.535 & 0.203 & 0.495 & 1.307 & 0.001 & 0.087 & 0.007 & 0.015 \\
\hline Chemicals and Petroleum & 0.791 & 0.215 & 0.506 & 1.521 & 0.029 & 0.057 & -0.019 & 0.026 \\
\hline Plastic and Leather & 0.232 & 0.326 & 0.558 & 1.530 & 0.095 & -0.020 & 0.009 & 0.017 \\
\hline Transport Communication & 0.499 & 0.324 & 0.543 & 1.129 & 0.065 & 0.055 & -0.019 & 0.028 \\
\hline Utilities & 0.519 & 0.373 & 0.503 & 1.242 & 0.051 & 0.022 & 0.001 & 0.024 \\
\hline Wholesale Retail & 0.541 & 0.130 & 0.386 & 1.382 & 0.026 & 0.028 & -0.039 & -0.020 \\
\hline Banking, Insurance & 1.085 & 0.151 & 0.565 & 1.592 & 0.020 & 0.015 & -0.003 & 0.012 \\
\hline Business, Personal Services & 0.564 & 0.290 & 0.427 & 1.528 & 0.037 & 0.050 & 0.040 & 0.027 \\
\hline Health Services & 0.921 & 0.352 & 0.518 & 1.654 & -0.008 & 0.106 & 0.009 & 0.015 \\
\hline
\end{tabular}


Table A.1 (ctd.). Summary statistics for the US

\begin{tabular}{l|ccc|ccc}
\hline \hline Sector name & $\begin{array}{c}\text { equipment } \\
\text { capital per } \\
\text { worker } \\
1970 \mathrm{~s}\end{array}$ & $\begin{array}{c}\text { \% change } \\
\text { equipment per } \\
\text { worker } \\
\text { 1980s-1970s }\end{array}$ & $\begin{array}{c}\text { \% change } \\
\text { equipment per } \\
\text { worker } \\
1990 \mathrm{~s}-1980 \mathrm{~s}\end{array}$ & $\begin{array}{c}\text { R\&D/value } \\
\text { added } \\
1970 \mathrm{~s}\end{array}$ & $\begin{array}{c}1 \text { 1st diff. } \\
\text { In(R\&D/va) } \\
1980 \mathrm{~s}-1970 \mathrm{~s}\end{array}$ & $\begin{array}{c}1 \text { st diff. } \\
\text { In(R\&D/va) } \\
1990 \mathrm{~s}-1980 \mathrm{~s}\end{array}$ \\
\hline \hline Agriculture and Mining & 349.05 & -0.089 & 0.323 & & & \\
Construction & 22.194 & -0.438 & -0.105 & & & 0.277 \\
Wood & 22.425 & -0.138 & -0.005 & 0.005 & -0.421 & -0.536 \\
Stone, Clay etc. & 55.550 & -0.068 & 0.113 & 0.019 & 0.530 & -0.371 \\
Primary Metals & 95.186 & 0.150 & 0.072 & 0.014 & 0.421 & 0.288 \\
Machinery & 23.435 & 0.198 & 0.389 & 0.023 & 0.398 & -0.178 \\
Electrical Machinery & 17.541 & 0.376 & 0.676 & 0.245 & 0.265 & -0.260 \\
Transport Equipment & 30.964 & -0.018 & 0.287 & 0.204 & 0.332 & 0.496 \\
Professional Goods & 11.392 & 0.822 & 0.613 & 0.120 & 0.095 & -0.045 \\
Food and Tobacco & 38.178 & 0.208 & 0.190 & 0.009 & 0.461 & 0.421 \\
Textiles & 20.046 & -0.114 & 0.330 & 0.003 & 0.440 & 0.571 \\
Paper and Printing & 43.389 & -0.015 & 0.336 & 0.008 & -0.022 & 0.038 \\
Chemicals and Petroleum & 92.144 & 0.020 & 0.261 & 0.100 & 0.207 & 0.085 \\
Plastic and Leather & 46.136 & -0.200 & 0.044 & 0.032 & -0.168 & \\
Transport Communication & 127.30 & -0.242 & 0.093 & & & \\
Utilities & 161.33 & -0.017 & 0.261 & & & \\
Wholesale Retail & 15.745 & 0.152 & 0.422 & & & \\
Banking, Insurance & 42.481 & 0.210 & 0.725 & & & \\
Business, Personal Services & 74.415 & -0.330 & 0.154 & & & \\
Health Services & 6.786 & 0.157 & 0.455 & & & \\
\hline \hline
\end{tabular}

Notes: Authors' calculations based on the data further described in the Data Appendix. 
Table A.2. Summary statistics for West Germany

\begin{tabular}{|c|c|c|c|c|c|c|c|c|}
\hline Sector name & $\begin{array}{c}H / L \\
1970 \mathrm{~s} \\
\end{array}$ & $\begin{array}{c}\text { 1st diff. } \ln (H / L) \\
1980 \mathrm{~s}-1970 \mathrm{~s}\end{array}$ & $\begin{array}{l}\text { 1st diff. } \ln (H / L) \\
1990 / 91-1980 \mathrm{~s}\end{array}$ & $\begin{array}{l}w h / w l \\
1970 s \\
\end{array}$ & $\begin{array}{c}\begin{array}{c}\text { 1st diff. } \\
\ln (w h / w l) \\
1980 \mathrm{~s}-1970 \mathrm{~s}\end{array} \\
\end{array}$ & $\begin{array}{c}\text { 1st diff. } \\
\ln (\mathrm{wh} / \mathrm{wl}) \\
1990 / 91-1980 \mathrm{~s}\end{array}$ & $\begin{array}{c}H / L \text { (vocational) } \\
1970 \mathrm{~s} \\
\end{array}$ & $\begin{array}{c}\text { H/L (vocational, } \\
\text { white-collar) } \\
1970 \mathrm{~s} \\
\end{array}$ \\
\hline Agriculture and Mining & 0.028 & 0.320 & 0.202 & 1.386 & -0.067 & -0.001 & 1.354 & 0.152 \\
\hline Construction & 0.025 & 0.242 & 0.131 & 1.385 & -0.011 & -0.021 & 3.543 & 0.144 \\
\hline Wood & 0.015 & 0.297 & 0.391 & 1.347 & -0.059 & 0.017 & 1.709 & 0.179 \\
\hline Stone, Clay etc. & 0.031 & 0.197 & 0.302 & 1.373 & 0.017 & -0.051 & 1.116 & 0.216 \\
\hline Primary Metals & 0.040 & 0.181 & 0.204 & 1.396 & 0.006 & -0.024 & 1.363 & 0.263 \\
\hline Machinery & 0.054 & 0.301 & 0.344 & 1.305 & 0.009 & -0.034 & 3.696 & 0.413 \\
\hline Electrical Machinery & 0.100 & 0.466 & 0.211 & 1.451 & -0.001 & -0.020 & 1.526 & 0.457 \\
\hline Transport Equipment & 0.046 & 0.340 & 0.241 & 1.314 & 0.029 & -0.016 & 2.540 & 0.303 \\
\hline Professional Goods & 0.043 & 0.478 & 0.305 & 1.414 & 0.016 & -0.011 & 1.741 & 0.337 \\
\hline Food and Tobacco & 0.019 & 0.272 & 0.331 & 1.486 & 0.016 & -0.023 & 2.028 & 0.441 \\
\hline Textiles & 0.017 & 0.252 & 0.414 & 1.585 & -0.003 & -0.076 & 0.956 & 0.212 \\
\hline Paper and Printing & 0.029 & 0.375 & 0.389 & 1.313 & 0.002 & -0.035 & 1.585 & 0.266 \\
\hline Chemicals and Petroleum & 0.084 & 0.296 & 0.311 & 1.338 & 0.006 & -0.050 & 1.647 & 0.494 \\
\hline Plastic and Leather & 0.019 & 0.618 & 0.467 & 1.572 & -0.050 & -0.036 & 0.855 & 0.225 \\
\hline Transport Communication & 0.029 & 0.404 & 0.315 & 1.226 & 0.017 & -0.008 & 2.233 & 0.350 \\
\hline Utilities & 0.082 & 0.210 & 0.255 & 1.243 & 0.001 & -0.041 & 5.072 & 0.596 \\
\hline Wholesale Retail & 0.040 & 0.271 & 0.306 & 1.366 & -0.004 & -0.013 & 4.464 & 1.613 \\
\hline Banking, Insurance & 0.095 & 0.556 & 0.451 & 1.199 & -0.076 & -0.029 & 5.486 & 4.045 \\
\hline Business, Personal Services & 0.170 & 0.216 & 0.208 & 1.519 & 0.010 & -0.011 & 3.679 & 1.250 \\
\hline Health Services & 0.092 & 0.322 & 0.198 & 1.491 & 0.067 & -0.079 & 3.377 & 2.045 \\
\hline
\end{tabular}


Table A.2 (ctd.). Summary statistics for West Germany

\begin{tabular}{|c|c|c|c|c|c|c|c|c|}
\hline Sector name & $\begin{array}{c}\text { equipment } \\
\text { capital per } \\
\text { worker } \\
1970 \mathrm{~s}\end{array}$ & $\begin{array}{l}\text { \% change } \\
\text { equipment per } \\
\text { worker } \\
\text { 1980s-1970s }\end{array}$ & $\begin{array}{c}\text { \% change } \\
\text { equipment per } \\
\text { worker } \\
\text { 1990/91-1980s }\end{array}$ & $\begin{array}{c}R \& D / \text { value } \\
\text { added } \\
1970 \text { s }\end{array}$ & $\begin{array}{c}\text { 1st diff. } \\
\ln (R \& D / v a) \\
1980 \mathrm{~s}-1970 \mathrm{~s}\end{array}$ & $\begin{array}{c}\text { 1st diff. } \\
\ln (R \& D / v a) \\
1990 / 91-1980 \mathrm{~s}\end{array}$ & $\begin{array}{c}\text { 1st diff. } \\
\text { In(hours) } \\
\text { 1980s-1970s }\end{array}$ & $\begin{array}{c}\text { 1st diff. } \\
\text { In(hours) } \\
\text { 1990/91-1980s }\end{array}$ \\
\hline Agriculture and Mining & 70.551 & 0.129 & 0.149 & & & & -0.055 & -0.039 \\
\hline Construction & 34.315 & -0.054 & 0.267 & & & & 0.007 & 0.043 \\
\hline Wood & 51.482 & -0.042 & 0.348 & 0.003 & 1.659 & -0.211 & -0.052 & -0.037 \\
\hline Stone, Clay etc. & 84.015 & 0.232 & 0.351 & 0.006 & 1.022 & -0.052 & -0.056 & -0.030 \\
\hline Primary Metals & 78.311 & -0.020 & 0.162 & 0.005 & 0.511 & -0.388 & -0.055 & -0.046 \\
\hline Machinery & 45.692 & 0.276 & 0.218 & 0.025 & 0.590 & -0.026 & -0.066 & -0.053 \\
\hline Electrical Machinery & 90.984 & 0.328 & 0.188 & 0.085 & 0.426 & 0.125 & -0.040 & -0.047 \\
\hline Transport Equipment & 84.626 & 0.441 & 0.219 & 0.057 & 0.540 & 0.294 & -0.060 & -0.043 \\
\hline Professional Goods & 47.866 & 0.051 & 0.320 & 0.018 & 0.421 & 0.189 & -0.051 & -0.042 \\
\hline Food and Tobacco & 74.982 & 0.061 & 0.320 & 0.003 & 0.913 & -0.192 & -0.033 & -0.040 \\
\hline Textiles & 31.349 & 0.243 & 0.404 & 0.002 & 0.923 & 0.116 & -0.030 & -0.050 \\
\hline Paper and Printing & 76.332 & 0.296 & 0.293 & 0.001 & 0.744 & -0.205 & -0.051 & -0.067 \\
\hline Chemicals and Petroleum & 147.45 & 0.001 & 0.247 & 0.072 & 0.405 & 0.210 & -0.045 & -0.038 \\
\hline Plastic and Leather & 51.406 & 0.337 & 0.327 & 0.009 & 0.798 & -0.120 & -0.034 & -0.049 \\
\hline Transport Communication & 114.34 & 0.132 & 0.138 & & & & -0.054 & -0.057 \\
\hline Utilities & 440.93 & 0.061 & -0.183 & & & & -0.027 & -0.044 \\
\hline Wholesale Retail & 29.485 & 0.050 & 0.327 & & & & -0.053 & -0.066 \\
\hline Banking, Insurance & 86.199 & 0.379 & 0.307 & & & & -0.123 & -0.045 \\
\hline Business, Personal Services & 42.617 & 0.040 & 0.082 & & & & -0.072 & -0.054 \\
\hline Health Services & 57.367 & -0.043 & 0.060 & & & & -0.045 & -0.044 \\
\hline
\end{tabular}

Notes: Authors' calculations based on the data further described in the Data Appendix. 
Table A.3. Industry classification for US data series

\begin{tabular}{|c|c|c|c|c|c|c|c|c|c|c|}
\hline $\begin{array}{l}\text { US } \\
\text { Sector } \\
\text { ID }\end{array}$ & Sector name & Capital stock & $\begin{array}{l}\text { Hours, } \\
\text { Value added } \\
\text { (van Ark) }\end{array}$ & $\begin{array}{l}R \& D \\
\text { STAN- } \\
\text { Anberd }\end{array}$ & $\begin{array}{l}\text { CPS } \\
1973-78 \\
\text { (ind70) } \\
\end{array}$ & $\begin{array}{l}\text { CPS } \\
1979-83 \\
\text { (ind70) } \\
\end{array}$ & $\begin{array}{l}\text { CPS } \\
83-93 \\
\text { (inddt) } \\
\end{array}$ & $\begin{array}{l}\text { CPS 94- } \\
02 \\
\text { (inddt) }\end{array}$ & $\begin{array}{l}\text { Cummins- } \\
\text { Violante deflator }\end{array}$ & $\begin{array}{l}\text { Cap. } \\
\text { inputs } \\
\text { (BEA, } \\
\text { Wilson) }\end{array}$ \\
\hline 1 & Agriculture and Mining & 2,5 & 1 to 4 & & 17 to 58 & 17 to 58 & 1 to 3 & 1 to 3 & 1 to 14 & 1 to 6 \\
\hline 3 & Construction & 10 & 33 & & 67 to 78 & 67 to 78 & 4 & 4 & 15 to 17 & 7 \\
\hline 4 & Wood & 13,14 & 9,31 & 103 & 107 to 118 & 107 to 118 & 5,6 & 5,6 & 24,25 & 8,9 \\
\hline 6 & Stone, Clay etc. & 15 & 15 & 110 & 119 to 138 & 119 to 138 & 7 & 7 & 32 & 10 \\
\hline 7 & Primary Metals & 16 & 16 & 111 & 139 to 149 & 139 to 149 & 8 & 8 & 33 & 11 \\
\hline 10 & Machinery & 18 & 18 & $\begin{array}{l}116 \\
117 \text { to }\end{array}$ & 177 to 198 & 177 to 198 & 11 & 11 & 35 & 13 \\
\hline 11 & Electrical Machinery & 19 & 19 to 22 & $\begin{array}{l}119 \\
120 \text { to }\end{array}$ & 199 to 209 & 199 to 209 & $\begin{array}{l}12 \\
13 \text { to }\end{array}$ & 12 & 36 & 14 \\
\hline 12 & Transport Equipment & 20,21 & 27 to 30 & 123 & 219 to 238 & 219 to 238 & 15 & 13 to 15 & 371,372 & 15,16 \\
\hline 15 & Professional Goods & 22 & 25 to 26 & 124 & 239 to 259 & 239 to 258 & 16 & 16 & 38, 39 & 17,18 \\
\hline 18 & Food and Tobacco & 25,26 & 5 & 101 & 268 to 299 & 268 to 299 & 19, 20 & 19, 20 & 20,21 & 19, 20 \\
\hline 20 & Textiles & 27,28 & 6,7 & 102 & 307 to 327 & 307 to 327 & 21,22 & 21,22 & 22,23 & 21,22 \\
\hline 22 & Paper and Printing & 29,30 & 10,11 & 104 & 328 to 339 & 328 to 339 & 23,24 & 23,24 & 26,27 & 23,24 \\
\hline 24 & Chemicals and Petroleum & 31,32 & 12,13 & 105 & 347 to 378 & 347 to 378 & 25,26 & 25,26 & 28,29 & 25,26 \\
\hline 26 & Plastic and Leather & 33,34 & 8,14 & 109 & 379 to 398 & 379 to 398 & 27,28 & 27,28 & 30,31 & 27,28 \\
\hline 28 & Transport Communication & 36,44 & 38 to 42 & & 407 to 449 & 407 to 449 & 29, 30 & 29, 30 & 40 to $47,481,483$ & 29 to 37 \\
\hline 30 & Utilities & 47 & 32 & & 467 to 479 & 467 to 479 & 31 & 31 & 491, 492, 495 & 38 to 40 \\
\hline 31 & Wholesale Retail & 51,52 & 34 to 36 & & 507 to 698 & 507 to 698 & 32, 33 & 32 to 34 & 50 to 59 & 41,42 \\
\hline 33 & $\begin{array}{l}\text { Banking, Insurance } \\
\text { Business, Personal }\end{array}$ & 53 & 43 to 46 & & 707 to 718 & 707 to 718 & 34,35 & 35,36 & 60 to $66,671,672$ & 43 to 51 \\
\hline 35 & Services & 64 to 71,73 to 75 & $37,47,48,49$ & & 727 to 817 & 727 to 817 & 36,40 & 37 to 41 & 70 to 79 & 52 to 58 \\
\hline 40 & Health Services & 72 & 54 & & 828 to 848 & 828 to 848 & 41,42 & 42,43 & 80 & 59 \\
\hline
\end{tabular}


Table A.4. Industry classification for West German data series

\begin{tabular}{|c|c|c|c|c|c|c|c|}
\hline $\begin{array}{l}\text { Germany } \\
\text { Sector ID }\end{array}$ & Sector name & $\begin{array}{l}\text { Gross } \\
\text { capital } \\
\text { formation }\end{array}$ & Depreciation & $\begin{array}{l}\text { Employment, } \\
\text { Value added }\end{array}$ & $\begin{array}{l}\text { Hours (van } \\
\text { Ark) }\end{array}$ & $\begin{array}{l}R \& D \\
\text { STAN- } \\
\text { Anberd } \\
\end{array}$ & $I A B$ \\
\hline 1 & Agriculture and Mining & 1,6 & 1,9 & $1,9,13$ & 1 to 4 & & $\begin{array}{l}0 \text { to } 3,5 \text { to } \\
8\end{array}$ \\
\hline 3 & Construction & 25 & 50 & 50 & 33 & & 59 to 61,25 \\
\hline 4 & Wood & 13 & 24 & 24 & 9,31 & 103 & 40,42 and 41 \\
\hline 6 & Stone, Clay etc. & 18 & 13 & 31 & 15 & 110 & 14 to 16 \\
\hline 7 & Primary Metals & 19 & 33 & 32 & 16 & 111 & 17 to 18 \\
\hline 10 & Machinery & 20 & 35 & 35 & 18 & 116 & 26 \\
\hline 11 & Electrical Machinery & 21 & 37 to 39 & $37,38,39$ & 19 to 22 & 117 to 119 & 33 to 34 \\
\hline 12 & Transport Equipment & 22 & 41 & 41 & 27 to 30 & 120 to 123 & 27 to 32 \\
\hline 15 & Professional Goods & 23 & 40 & 40 & 23 to 25 & 124 & 35 to 36 \\
\hline 18 & Food and Tobacco & 10 & 17 & 17 & 5 & 101 & 54 to 57 \\
\hline 20 & Textiles & 11 & 20 & 20 & 6,7 & 102 & 47 to 53 \\
\hline 22 & Paper and Printing & 14 & 25 & 25 & 10,11 & 104 & 43 to 44 \\
\hline 24 & Chemicals and Petroleum & 15,16 & 28,29 & 28,29 & 12,13 & 105 & 9 to 11 \\
\hline 26 & Plastic and Leather & 12,17 & 30 & 23,30 & 8,14 & 109 & 12 to 13,45 to 46 \\
\hline 28 & Transport Communication & 29 & 58 & 58 & 38 to 42 & & 63 to 68 \\
\hline 30 & Utilities & 24 & 47 & 47 & 32 & & 4 \\
\hline 31 & Wholesale Retail & 27 & 53 & 53 & 34 to 36 & & 62 \\
\hline 33 & $\begin{array}{l}\text { Banking, Insurance } \\
\text { Business, Personal }\end{array}$ & 30 & 64 & 64 & 43 to 46 & & 69,81 \\
\hline 35 & Services & 37,28 & 79 & 57,79 & $37,47,48$ & & 70 to 77,79 to 80,82 to 83,85 to 86 \\
\hline 40 & Health Services & 36 & 78 & 78 & 54 & & 78,84 \\
\hline
\end{tabular}

